\title{
Catheter-Associated Urinary Tract Infections in the Adult Patient Group: A Qualitative Systematic Review on the Adopted Preventative and Interventional Protocols From the Literature
}

Mohamed H. Gad ${ }^{1}$, Hesham H. AbdelAziz ${ }^{2}$

1. Surgery, The Queen Elizabeth Hospital King's Lynn NHS Foundation Trust, King's Lynn, GBR 2. Urology, Al Soliman Hospital, Port Said, EGY

Corresponding author: Mohamed H. Gad, mh2mgroup@aol.com

\begin{abstract}
Catheter-associated urinary tract infections (CA-UTIs) are among the most common nosocomial infections acquired by patients in health care settings. A significant risk factor for CA-UTIs is the duration of catheterization. To summarize the current strategies and interventions in reducing urinary tract infections associated with urinary catheters, use and the need for re-catheterization on the rate of CA-UTIs, we performed a systematic review. A rapid evidence analysis was carried out in the Medline (via Ovid) and the Cochrane Library for the periods of January 2005 till April 2021. The main inclusion criterion required to be included in this review was symptomatic CA-UTI in adults as a primary or secondary outcome in all the included studies. Only randomized trials and systematic reviews were included, reviewed, evaluated, and abstracted data from the 1145 articles that met the inclusion criteria. A total of 1145 articles were identified, of which 59 studies that met the inclusion criteria were selected. Studies of relevance to CA-UTIs were based on: duration of catheterization, indication for catheterization, catheter types, UTI prophylaxis, educational proposals and approaches, and mixed policies and interventions. The duration of catheterization is the contributing risk factor for CA-UTI incidence; longer-term catheterization should only be undertaken where needed indications. The indications for catheterization should be based on individual base to base cases. The evidence for systemic prophylaxis instead of when clinically indicated is still equivocal. However, antibioticimpregnated catheters reduce the risk of symptomatic CA-UTIs and bacteriuria and are more cost-effective than other impregnated catheter types. Antibiotic resistance, potential side effects and increased healthcare costs are potential disadvantages of implementing antibiotic prophylaxis.
\end{abstract}

Multiple interventions and measures such as reducing the number of catheters in place, removing catheters at their earliest, clinically appropriate time, reducing the number of unnecessary catheters inserted, decrease antibiotic administration unless clinically needed, raising more awareness and provide training of nursing personnel on the latest guidelines, can effectively lower the incidence of CA-UTIs.

Review began 06/21/2021 Review ended 06/28/2021 Published 07/09/2021

\section{๑) Copyright 2021}

Gad et al. This is an open access article distributed under the terms of the Creative Commons Attribution License CC-BY 4.0., which permits unrestricted use, distribution, and reproduction in any medium, provided the original author and source are credited.
Categories: Urology, Infectious Disease

Keywords: catheter-associated urinary tract infection, urinary tract infection, urinary catheterization, indwelling catheterization, asymptomatic bacteriuria, catheter-associated bacteriuria, intervention studies

\section{Introduction And Background}

Catheter-associated urinary tract infection (CA-UTI) is defined as a urinary tract infection that occurs with the use of an indwelling urinary catheter. A prevalence survey from 2006 about hospital-acquired infections in acute hospitals in Ireland revealed that UTIs account for $22.5 \%$ in a hospital setting, of which $56.2 \%$ were catheter-related [1]. A urinary tract infection (UTI) is an infection to the epithelium of the urinary tract in response to the colonization of the pathogen. Urinary tract infections (UTIs) are one of the most common hospital community-acquired infections (HCAI), with up to $70-80 \%$ attributable to the presence of indwelling urinary catheters [2]. Between $10 \%$ to $25 \%$ of hospitalized patients, during their hospitalization, will receive indwelling urinary catheters, of whom $20 \%$ develop UTIs [3,4]. The risk of catheter-related infection increases by $5 \%$ each subsequent day the catheter remains in situ, with the risk increasing to $35 \%$ and $70 \%$ after seven and 14 days of indwelling catheterization, respectively. Around $50 \%$ of patients with indwelling catheters after 15 days of installation will develop UTIs, and almost 100\% of the patients will develop UTI in one month [5]. Results of the 2009 pilot study for the European HCAI (HALT) study in longterm care facilities revealed that urinary tract infections accounted for $30 \%$ of the reported HCAIs and that almost half of all systemic antimicrobials were prescribed for an indication related to the urinary tract $(48.9 \%)$ [6].

In line with the literature findings, it is clear that there is no standardization or even consensus among practitioners and hospitals/institutions regarding the protocols carried out of urinary catheter's insertion and maintenance. Regarding antibiotics prophylaxis, type of catheter to use, dwell time of the catheter, periurethral cleansing with anti-septic or sterile solutions etc., non-standardized practices in managing catheterized patients are noticed. A study by Conway et al. revealed that implementation protocol guidelines for CA-UTI prevention in the ICUs (intensive care units) is inadequate and insufficient, with $42 \%$ of ICUs reported having existing evidence-based practices (EBP) and policies for prophylaxis [7]. Therefore, there is a need for competent healthcare workers to set up and adhere to preventive and management protocols to reduce the probability of catheter-related infection. This article aims to provide a general overview of urinary catheterization and its association with UTI and preventative strategies by presenting the available results and recommendations in the literature.

\section{Review}

\section{Method}

A literature search was carried out in April 2021 in the Medline (via Ovid) and the Cochrane Library 


\section{Cureus}

databases. Our searches used the following joint search term variations of the following Medical Subject Heading terms, specifically tailored for each database. The search terms- "urinary tract infections," "bacteriuria," "catheter," "indwelling catheter," "urinary catheterization," "asymptomatic bacteriuria," "intervention studies"-were looked at both as free texts and MesH terms. We also evaluated the reference lists of articles, which provided us with further articles for consideration. Only full-text publications in English were considered. While catheter-associated asymptomatic bacteriuria was mentioned and compared to CA-UTI, it was decided not to be included.

Study Selection

A rapid evidence analysis was carried out in the Medline (via Ovid) and the Cochrane Library for January 2005 to April 2021. The main inclusion criterion required to be included in this review was symptomatic catheter-associated UTI in adults as a primary or secondary outcome in all the included studies. Only randomized trials and systematic reviews were included in this systematic analysis. One thousand one hundred forty-five articles were identified, of which 1086 were excluded, as explained in figure 1 . The final review is thus based on 59 articles.

Data Extraction and Quality Assessment

The two authors of this review (HA and MG) independently reviewed and abstracted data from the 1145 articles that met the inclusion criteria. Extracted data included primary study objectives, patient population characteristics, inclusion criteria, terms and definitions used and quality issues. The data from the literature search were evaluated and shortlisted by the first author according to methodological/theoretical rigor and trustworthiness and data relevance on CA-UTI as a primary or secondary outcome.

Study Characteristics for Inclusion

Our database search included publications published in the English language. We did not exclude studies based on the number of residents or patients included (gender, age, catheter type, use of antibiotic), duration of pre and post-intervention periods, study withdrawals, or whether follow-ups were done or not.

Data Source and Searching the Literature

The following data sources were searched: Ovid MEDLINE, Cochrane Library via Wiley and CINAHL. Only systematic search strategies were performed in the process of collecting the data (Figure 1). The first systematic search was conducted using the previously mentioned data sources to find searches associated with indications and need for catheterization, type of catheterization, duration of catheterization, infection prophylaxis, education programs, and interventions at reducing UTIs. The second systematic search was conducted in the described above data sources Ovid MEDLINE \& Cochrane to identify RCT or studies to reduce UTI incidences use of antimicrobial coated catheters in settings such as hospitals, nursing homes, communities and rehabilitation units and spinal cord injury or orthopaedic programs, which do compromise a considerable population with chronic catheter needs.

Study Selection \& Data Extraction

A data collection instrument was adapted and used for characterization of the selected studies containing items such as the descriptors used, title, authors, area of work, year of publication, language, design, objectives, method, results, conclusion, recommendations, limitations and level of scientific evidence, among others. The three phases of this systematic review are detailed in figure 1 [8]. 


\section{Cureus}

PRISMA 2020 flow diagram for new systematic reviews which included searches of databases and registers only

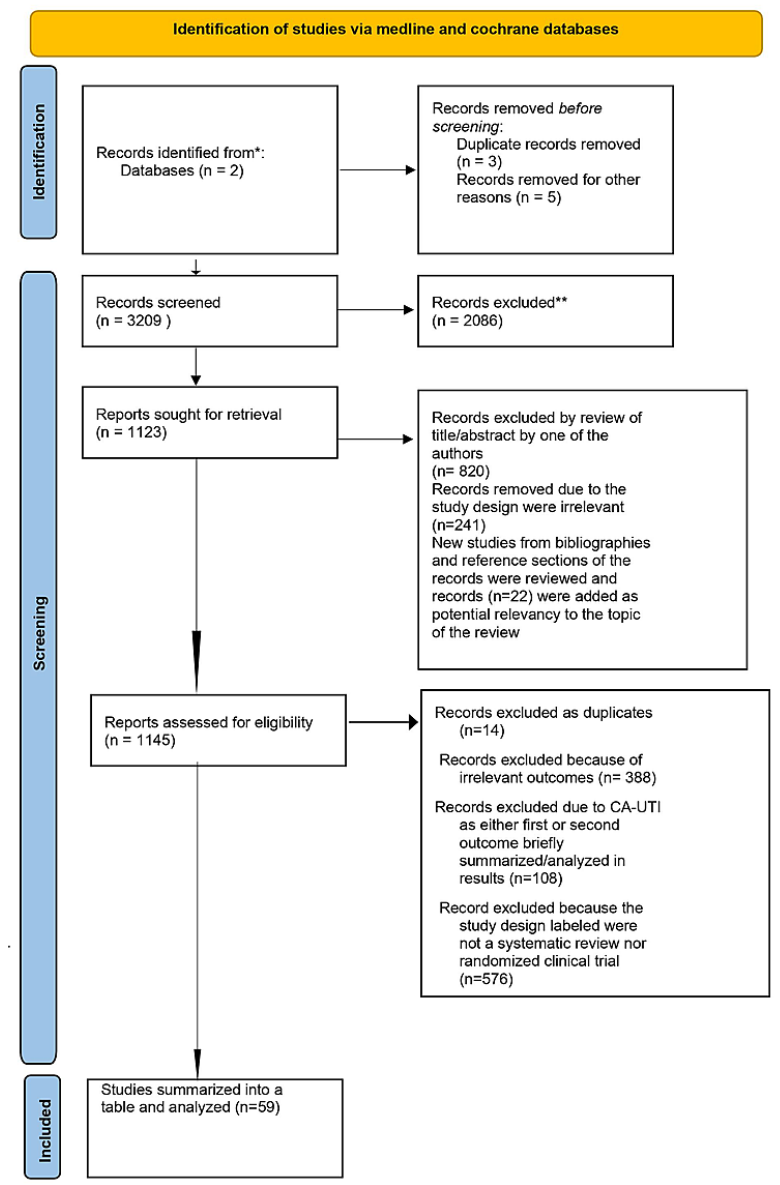

FIGURE 1: PRISMA 2020 flow diagram of the three phases of the systematic review.

PRISMA 2020 flow diagram of the three phases of the systematic review [8]. For more information, visit: http://www.prisma-statement.org/prismastatement/flowdiagram.aspx

The first systematic search was filtered by title and abstract and applied a few exclusions (no symptomatic UTI/CA-UTI related outcomes were analyzed), identified duplicate studies, reviewed, and assigned potentially relevant studies and categorized them into groups such as review articles, clinical trials, comparative studies, and meta-analyses. Co-authors HA \& MG filtered the records by title and abstract and reviewed the reference lists, of the included studies in this review, for additional relevant articles. Each author scored the studies, and the individually obtained results were later compared. Both authors' discrepancies in the scores were re-revised to ensure that the doubts concerning each studies inclusion were eliminated. Duplicates were removed. As exclusion criteria, the authors chose articles with non-relevancy to the issue of urinary catheterization, UTI or CA-UTI.

The Jadad scale assessed the selected articles for evaluating the methodological quality of the selected RCT. The articles were graded from zero to five according to their methodological rigor and quality. One point is awarded for each of the following three questions: the description of randomization, the method of blinding, and withdrawals and dropouts. An extra point is attributed for each appropriately described randomization and blinding, up to a maximum of five points. A score of over three points constitutes an RCT of methodological rigor, and under three points were lower thoroughness. The extracted data from the 59 studies which made up this review are included in the results and discussion sections.

Outcomes

We researched studies including CA-UTI from the usage of an indwelling Foley urinary catheter or CA-UTI due to other catheter types such as intermittent or suprapubic catheters.

\section{Results}




\section{Cureus}

Analysis of the Literature Search

The database search yielded 1145 results (Figure 1), of which 59 relevant studies were included in this review (Table 1$)$. The included studies are grouped thematically: duration of catheterization $(n=9)$, type of catheterization ( $n=13)$, assessing indication/necessity for catheterization $(n=2)$, maintenance and care of catheterized patients $(n=5)$, prophylactic measures $(n=17)$, preventative and/ or educational initiatives $(n=$ 10 ), and studies with multiple interventions $(\mathrm{n}=3)$. A total of 23 systematic reviews (including 6 Cochrane reviews) and 36 randomized, controlled trials (RCTs) were identified.

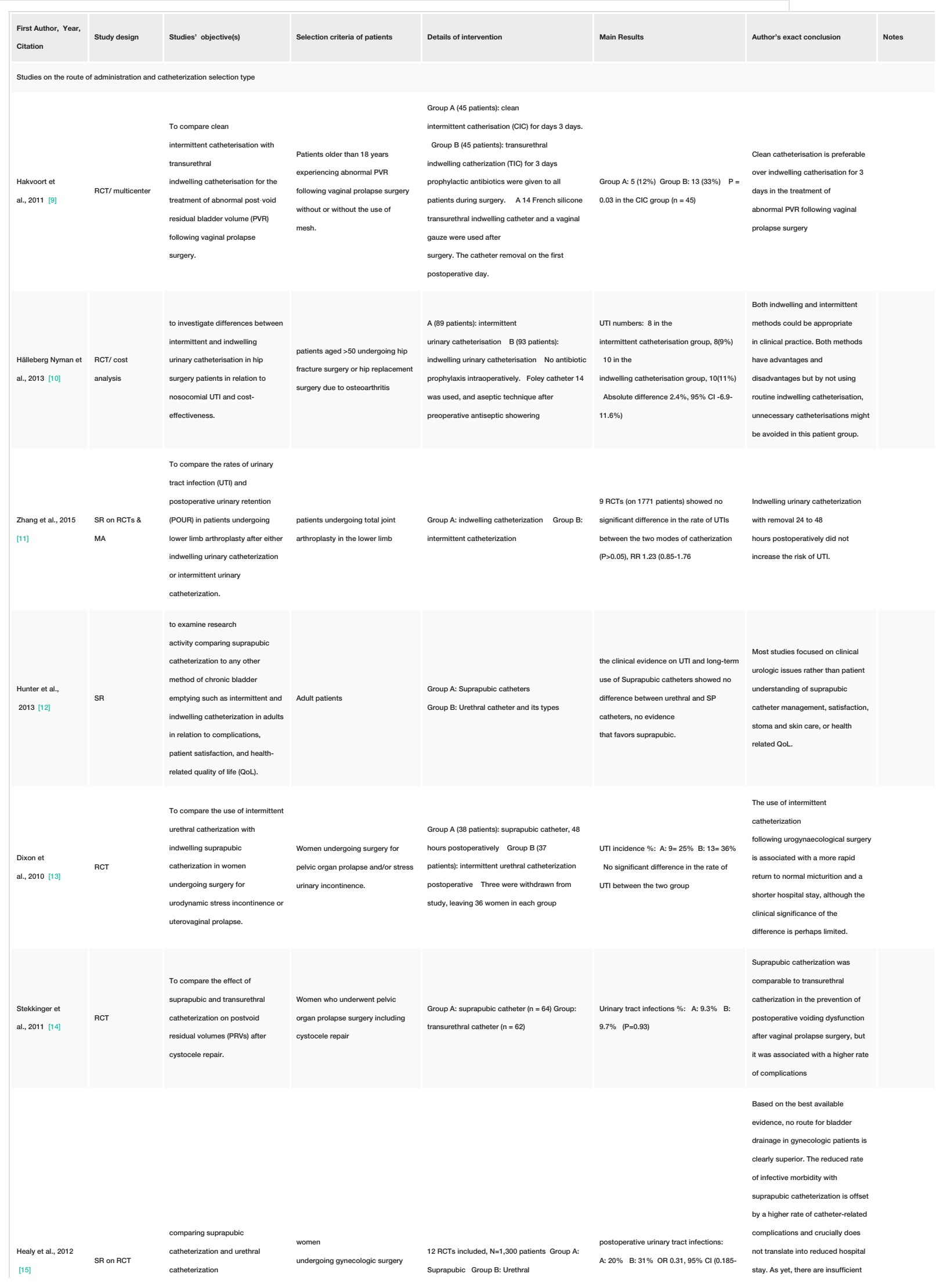




\section{Cureus}

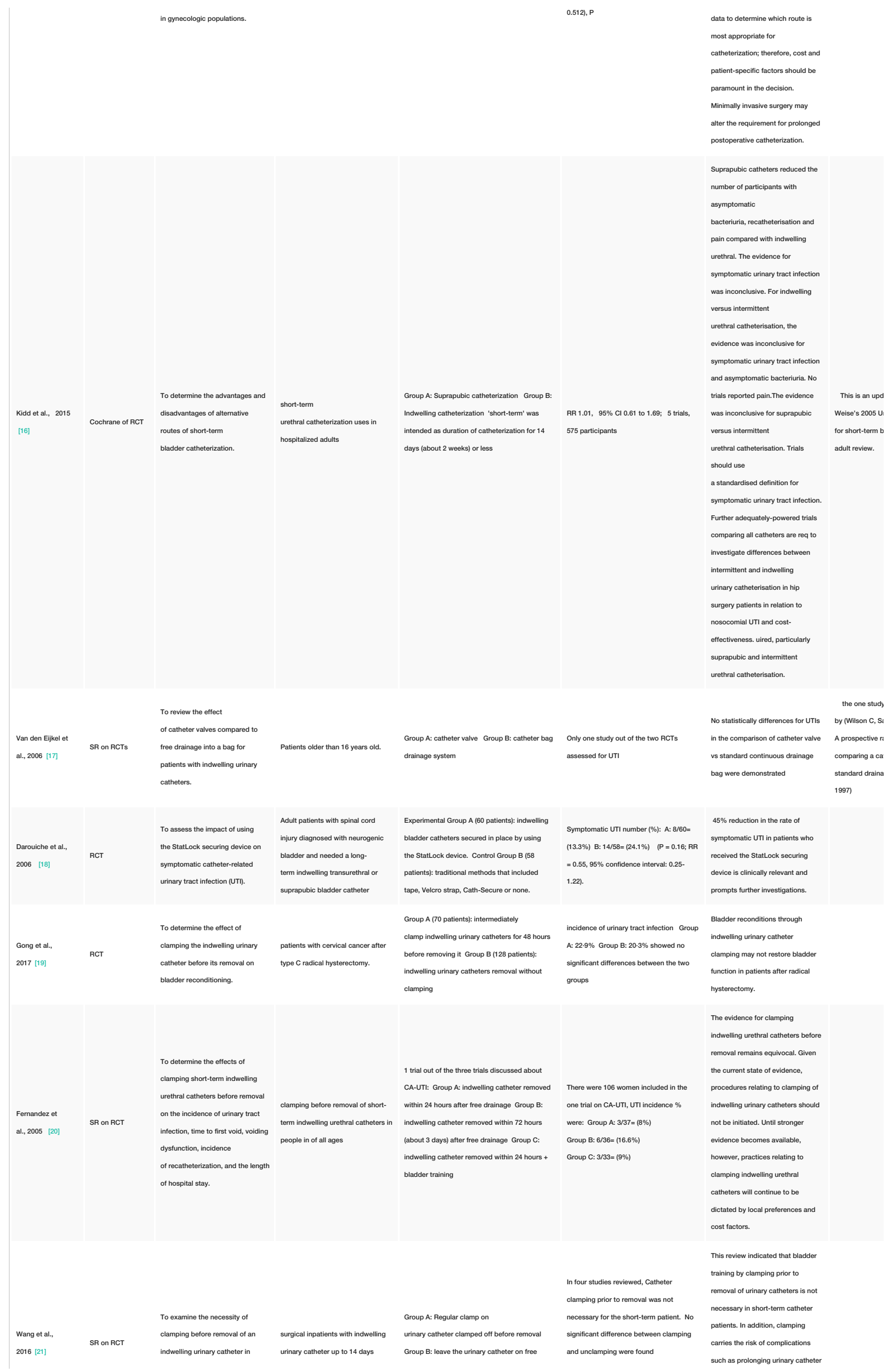




\section{Cureus}

\begin{tabular}{|c|c|c|c|c|c|c|}
\hline & & \multicolumn{2}{|l|}{ short-term patients. } & draining until removal & $\begin{array}{l}\text { in recatheterization risk, nor rate of urinary } \\
\text { tract infection. OR } 0.76,95 \% \mathrm{Cl}(0.33 \text {, } \\
\text { 1.73) }\end{array}$ & $\begin{array}{l}\text { retention and urinary tract injury. } \\
\text { Further investigation requires higher } \\
\text { quality methodologies and more } \\
\text { diverse study designs. }\end{array}$ \\
\hline \multicolumn{7}{|c|}{ Duration of catheterization and dwell time } \\
\hline $\begin{array}{l}\text { Alessandri et } \\
\text { al., } 2006[22]\end{array}$ & RCT & $\begin{array}{l}\text { Assessing immediate versus } \\
\text { delayed catheter removal. }\end{array}$ & $\begin{array}{l}\text { randomly assigned who } \\
\text { underwent hysterectomy for various } \\
\text { benign diseases. }\end{array}$ & $\begin{array}{l}\text { three groups ( } 32 \text { women for each group). } \\
\text { Group A: immediate removal of the catheter in } \\
\text { the operating room. } 2 \text {. Group B: removal } \\
\text { of catheter at } 6 \mathrm{~h} \text { after the operation. 3. Group } \\
\text { C: removal of catheter at } 12 \mathrm{~h} \text { after the } \\
\text { operation. All patients received a single dose of } \\
\text { antibiotic prophylaxis before hysterectomy. } 16 \mathrm{~F} \\
\text { latex catheters with a } 10 \mathrm{ml} \text { balloon were } \\
\text { used as well. }\end{array}$ & $\begin{array}{l}\text { Symptomatic urinary infection in the three } \\
\text { groups (\%): A: } 1 / 32=3.1 \text { B: } 4 / 30=13.3 \\
\text { C: } 5 / 32=15.6\end{array}$ & $\begin{array}{l}\text { There could be an association } \\
\text { between necessity of re- } \\
\text { catheterization and the type of } \\
\text { surgery (NH) or the type } \\
\text { of anesthesia (spinal). Despite re- } \\
\text { catheterization rate, early removal } \\
\text { of indwelling catheters immediately } \\
\text { after uncomplicated hysterectomy } \\
\text { seems to decrease first ambulation } \\
\text { time and hospital stay. }\end{array}$ \\
\hline $\begin{array}{l}\text { Sekhavat et al., } \\
2008[23]\end{array}$ & RCT & $\begin{array}{l}\text { To assess whether immediate } \\
\text { removal of an indwelling catheter } \\
\text { after anterior colpornaphy } \\
\text { influences the rate of re- } \\
\text { catheterisation and symptomatic } \\
\text { urinary tract infections. }\end{array}$ & $\begin{array}{l}90 \text { women aged between } 40 \text { and } 50 \\
\text { years who underwent anterior } \\
\text { colporrhaphy. }\end{array}$ & $\begin{array}{l}\text { The women were divided into two groups: A: } \\
\text { removal immediately after surgery B: removal } \\
\text { at least } 24 \mathrm{~h} \text { after OP } \mathrm{n}=45 \text { for both groups }\end{array}$ & $\begin{array}{l}\text { UTI percentage (supported with positive } \\
\text { urine culture): Group A: } 4,5 \% \text { Group B: } \\
15,5 \% \mathrm{P}=0,01\end{array}$ & $\begin{array}{l}\text { Early removal of an indwelling } \\
\text { catheter immediately after anterior } \\
\text { colporrinhaphy was not associated } \\
\text { with adverse events and an } \\
\text { increased rate of re-catheterization. } \\
\text { In this group, symptomatic urinary } \\
\text { tract infection was significantly } \\
\text { lower. Moreover, early removal of } \\
\text { indwelling catheters immediately } \\
\text { after operation seemed to decrease } \\
\text { the ambulation time and hospital } \\
\text { stay. }\end{array}$ \\
\hline $\begin{array}{l}\text { Chai et al., } 2011 \\
\text { [24] }\end{array}$ & RCT & $\begin{array}{l}\text { To assess whether early or } \\
\text { immediate removal of a } 12 \mathrm{~F} \text { in- } \\
\text { dwelling Foley catheter after total } \\
\text { abdominal hysterectomy affects } \\
\text { the level of subjective pain } \\
\text { assessment postoperatively. }\end{array}$ & $\begin{array}{l}\text { Women undergoing total abdominal } \\
\text { hysterectomy for various } \\
\text { benign gynecological diseases } \\
\text { after counseling about available } \\
\text { alternative treatments. }\end{array}$ & $\begin{array}{l}\text { Two designated groups: Group A } 35 \\
\text { patients): catheter removed immediately post- } \\
\text { surgery Group B ( } 35 \\
\text { patients): catheter removed on a postoperative } \\
\text { day one, i.e. } 24 \text { hours after the operation } \\
\text { Latex } 12 F \text { with a } 10 \mathrm{ml} \text { balloon Foley catheter } \\
\text { under aseptic technique and catheter urine } \\
\text { were collected for microscopy and culture. } \\
\text { Routine prophylactic antibiotics were not given. }\end{array}$ & $\begin{array}{l}\text { symptomatic urinary tract infection, } \mathrm{n} \\
(\%): \mathrm{A}: 1=(2.9) \mathrm{B}: 3=(8.6)\end{array}$ & $\begin{array}{l}\text { There are pros and cons regarding } \\
\text { the policy of one-day in-dwelling } \\
\text { catheterization compared to } \\
\text { immediate catheter removal. }\end{array}$ \\
\hline $\begin{array}{l}\text { Ahmed et al., } \\
2014[25]\end{array}$ & RCT & $\begin{array}{l}\text { assess whether immediate (oh), } \\
\text { intermediate (after 6h) or delayed } \\
\text { (after 24h) removal of an } \\
\text { indwelling urinary catheter after } \\
\text { uncomplicated abdominal } \\
\text { hysterectomy can affect the rate } \\
\text { of re-catheterization due to urinary } \\
\text { retention, rate of urinary tract } \\
\text { infection, ambulation time and } \\
\text { length of hospital stay. }\end{array}$ & $\begin{array}{l}221 \text { women underwent total } \\
\text { abdominal hysterectomy for } \\
\text { benign gynaecological diseases } \\
\text { and were randomly distributed into } \\
\text { three groups. On the moming of } \\
\text { surgery, all patients received a } \\
\text { single dose of } \\
\text { prophylactic antibiotic (ceftriaxone } \\
\text { 19) intramuscularly. }\end{array}$ & $\begin{array}{l}\text { Group A }(73 \\
\text { patients): catheter removed immediately after } \\
\text { surgery ( } 0 \text { h) Group B ( } 81 \\
\text { patients): catheter removed } 6 \mathrm{~h} \text { post-surgery } \\
\text { Group C ( } 67 \text { patients): catheter removed } 24 \mathrm{~h} \\
\text { post-surgery size } 12 \text { latex Foley's catheter were } \\
\text { used. }\end{array}$ & $\begin{array}{l}\text { Symptomatic UT1, n (\%): Group A: } 1= \\
(1,4) \text { Group B: } 3=(3,7) \text { Group C: } 10= \\
(14,9) \quad(p=0.008)\end{array}$ & $\begin{array}{l}\text { Removal of the urinary catheter } 6 \mathrm{~h} \\
\text { postoperatively appears to be more } \\
\text { advantageous than early or late } \\
\text { removal in cases of uncomplicated } \\
\text { total abdominal hysterectomy. }\end{array}$ \\
\hline $\begin{array}{l}\text { El-Mazny et al., } \\
2014 \text { [26] }\end{array}$ & RCT & $\begin{array}{l}\text { To compare immediate and } 12 \mathrm{~h} \\
\text { postoperative removal of urinary } \\
\text { catheter after } \\
\text { elective cesarean section. }\end{array}$ & $\begin{array}{l}300 \text { eligible women admitted for } \\
\text { primary or repeat } \\
\text { elective cesarean section. }\end{array}$ & $\begin{array}{l}\text { The women were randomized into two equal } \\
\text { groups: Group } A(n=150) \text { : catheter was } \\
\text { removed immediately after the procedure } \\
\text { Group B ( } n=150) \text { : the catheter was removed } 12 \mathrm{~h} \\
\text { postoperatively. Foley urethral catheter was } \\
\text { used and antibiotic prophylaxis was given to all } \\
\text { patients. }\end{array}$ & 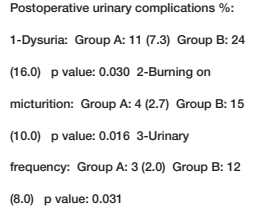 & $\begin{array}{l}\text { Immediate removal of urinary } \\
\text { catheters after } \\
\text { elective cesarean section is } \\
\text { associated with a lower risk of } \\
\text { urinary infection and earlier } \\
\text { postoperative ambulation. }\end{array}$ \\
\hline $\begin{array}{l}\text { Bray et al, } 2017 \\
\text { [27] }\end{array}$ & RCT & $\begin{array}{l}\text { To determine if } \\
\text { indwelling catheterisation is } \\
\text { necessary after vaginal surgery for } \\
\text { pelvic organ prolapse. }\end{array}$ & $\begin{array}{l}\text { immediate post-operative removal } \\
\text { of catheter compared to a } \\
\text { suprapubic catheter (SPC) after } \\
\text { vaginal prolapse surgery via the } \\
\text { vaginal route. }\end{array}$ & $\begin{array}{l}\text { Two groups were created: Group A ( } 29 \\
\text { patients): Suprapubic catheter until } 48 \mathrm{~h} \text { (day } \\
\text { 2) postoperative. Group B ( } 31 \text { patients): } \\
\text { immediate removal of one dose of intraoperative } \\
\text { prophylactic antibiotics administered. }\end{array}$ & $\begin{array}{l}\text { Rate of symptomatic bacteriuria (n): A: } 15 \\
\text { B: } 5 \text { (p<0.01) }\end{array}$ & $\begin{array}{l}\text { Early removal of a catheter reduces } \\
\text { urinary tract infection and } \\
\text { significantly decreases hospital } \\
\text { stay. Such a policy should result in } \\
\text { improved patient satisfaction and } \\
\text { reduced hospital costs. }\end{array}$ \\
\hline $\begin{array}{l}\text { Weemhoff et al., } \\
2011[28]\end{array}$ & RCT & $\begin{array}{l}\text { compare the number of temporary } \\
\text { catheter replacements and urinary } \\
\text { tract infections after indwelling } \\
\text { catheterization for } 2 \text { versus } 5 \text { days } \\
\text { following an anterior } \\
\text { colporrhaphy. }\end{array}$ & $\begin{array}{l}246 \text { patients with cystocele } \\
\text { undergoing an anterior } \\
\text { colporrhaphy were eligible }\end{array}$ & $\begin{array}{l}\text { Two groups were assigned } \\
\text { Group A: catheter for } 2 \text { days } \\
\text { Group B: catheter for } 5 \text { days }\end{array}$ & $\begin{array}{l}\text { Urinary tract infection percentage: } \\
\text { Group A: } 22 \% \text {, proven by a culture with } \\
>105 \text { colony forming units per milliliter, } \\
\text { Group B: } 37 \% \text { OR= } 0.5(\mathrm{Cl} 0.3-0.9, \mathrm{p}= \\
0.02)\end{array}$ & $\begin{array}{l}\text { Removal of an indwelling catheter } \\
\text { after } 2 \text { versus } 5 \text { days following } \\
\text { anterior colporrhaphy is associated } \\
\text { with more temporary catheter } \\
\text { replacements, but fewer urinary } \\
\text { tract infections and a shorter } \\
\text { hospital stay. }\end{array}$ \\
\hline & & $\begin{array}{l}\text { to assess the impact of bladder } \\
\text { catheterization on the incidence of }\end{array}$ & & & & $\begin{array}{l}\text { although the incidence of catheter- } \\
\text { associated UTI following LAVH was } \\
\text { confounded by the use of } \\
\text { prophylactic antibiotics in our } \\
\text { study, the data suggest that the }\end{array}$ \\
\hline
\end{tabular}




\section{Cureus}

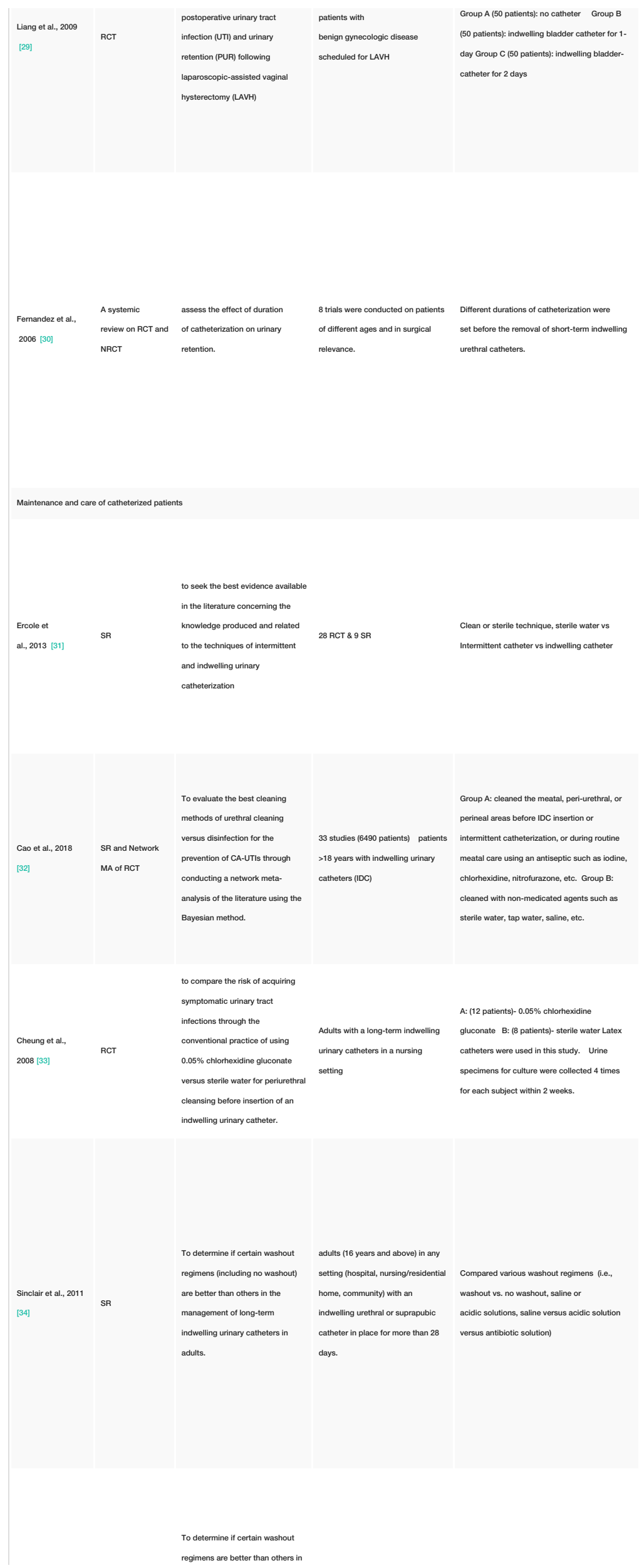
UTI: Group A: 2 (4\%) Group B: 3
(6\%) Group C: $9(18 \%) \quad(p=0.034)$

(a)

Immediate versus within 24-48

hours versus after 48 -hour removal of

indwelling catheters Four of the trials o

of the eight proved no significant

differences statistically in patient

outcome with an incidence of UTIs after

TURP (RR 0.55, 95\% Cl 0.30 to 1.03 ). $\quad 1$

trial of patients who had their indwelling

urethral catheters removed 5 days after

rectal resection reported a higher

incidence of urinary tract infection, in

comparison to the patients who had

their indwelling urethral catheters

removed 1 day after surgery (RR 0.48,

$95 \%$ Cl 0.27 to 0.85 .

he infection rate in the urinary tract does

not vary whether using sterile or non-

sterile methods. The use of an

intermittent catheter with a clean

technique results in low rates of

complications or infections compared to

the use of an indwelling catheter. The

removal of the catheter up to 24 hours

after surgery and the use of an

antimicrobial-impregnated are favoured.

7 different methods of urethral cleaning

versus disinfection were eligible for

inclusion, no heterogeneity in the

incidence of CA-UTIS documented in the

studies The 7 urethral cleaning methods

versus disinfection resulted in $(P>0.05)$

for both, no difference in the incidence of

CA-UTIs. Chlorhexidine ranked first in

the results of the Bayesian analysis and is

recommended for preventing CA-UTIS.

there are controversies in relation

to the periurethral cleansing

technique, the type of material the

catheter is made of, and some

procedures for the maintenance

and removal of the catheter.

there are no significant differences

among different urethral cleaning

versus disinfection methods with

regard to CA-UTI incidence rates.

Using sterile water to clean the

periurethral area before

catheterization among home care

patients will not increase the risk for

urinary tract infections.

The data from five trials comparing
differing washout policies were
sparse and trials were generally of
poor quality or poorly reported. The
evidence was too scant to
conclude whether or not washouts
were beneficiial. Further rigorous,
high-quality trials with adequate
power to detect any benefit from
washout rather than no washout
being performed are required in the
first instance. After that, trials
comparing different washout
solutions, washout volumes,
frequencies/timings, and routes of
administration are needed.
Data from seven trials that
compared different washout
policies were limited, and generally,
of poor methodological quality or




\section{Cureus}

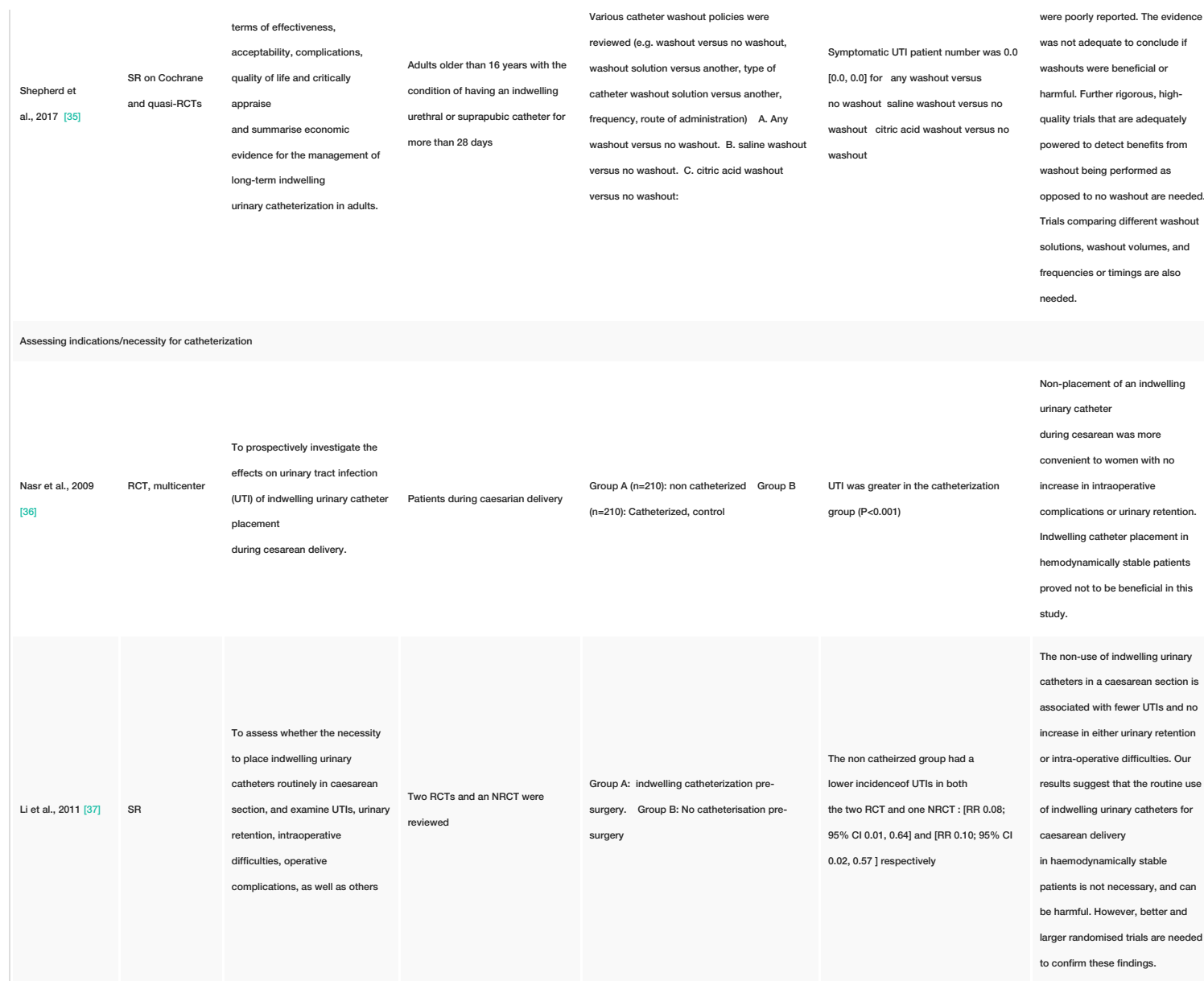

Studies on UTI prophylaxis
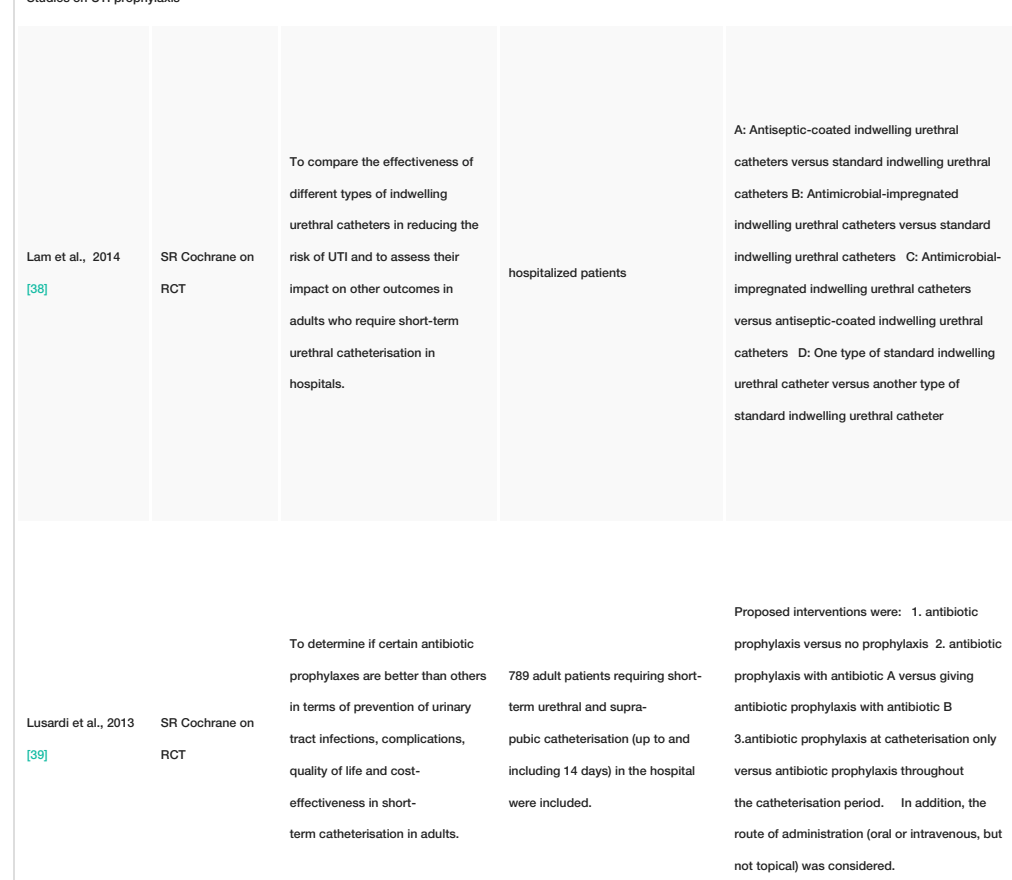

Silver alloy-coated catheters were

not associated with a statistically

significant reduction in

symptomatic CA-UTI, and are

considerably more expensive.

CA-UT: A: RR 0.99, $95 \%$ Cl 0.85 to 1.16 Nitrofurazone-impregnated

B: RR0.84, 95\%C1 0.71 to $0.99 \quad$ C: RR catheters reduced the risk of

$0.84,95 \%$ Cl 0.71 to 1.00 D: $\quad$ symptomatic CA-UTI and

Trials included the standard catheter did bacteriuria, although the magnitude

not measure symptomatic CA-UTL.

may not be clinically important.

However, they are more expensive

than standard catheters. They are

also more likely to cause discomfort

than standard catheters.

The limited evidence indicated that

receiving prophylactic antibiotics

reduced the rate of bacteriuria and

other signs of infection, such as

pyuria, febrile morbidity and gram-

prophylaxes are better than others 789 adult patients requiring short-

in terms of prevention of urinary term urethral and supra-

pubic catheterisation (up to and

Lusardi et al., $2013 \quad$ SR Cochrane on

[39]

RCT

quality of life and cost-

including 14 days) in the hospita

effectiveness in shortwere included.

not topical) was considered.

UTI as a result from antibiotic prophylaxis

versus no prophylaxis (based on 1 trial

negative isolates in patients' urine

in surgical patients who undergo

bladder drainage for at least 24

hours postoperatively. There was

also limited evidence that

prophylactic antibiotics reduced

bacteriuria in non-surgical

patien

The trial estimate of clinical

effectiveness for nitrofurazone-

impregnated catheters was less

than the pre-specified minimum

absolute risk difference that we

considered important $(-3.3 \%)$, anc

the surrounding $\mathrm{Cl}$ included zero,

indicating that any reduction in 


\section{Cureus}

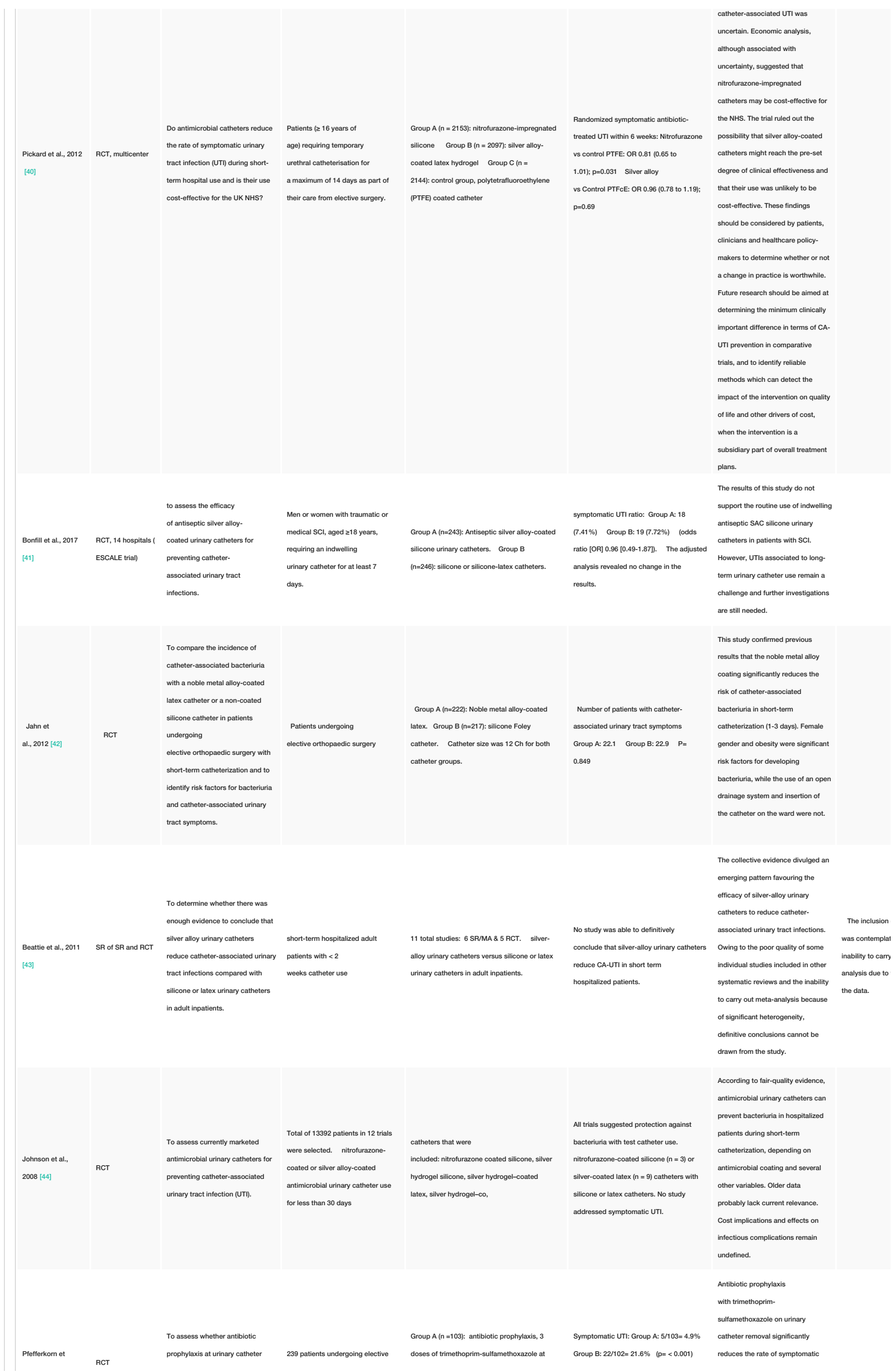




\section{Cureus}

\begin{tabular}{|c|c|c|c|c|c|c|}
\hline al., 2009 [45] & & $\begin{array}{l}\text { removal reduces the rate of } \\
\text { urinary tract infections }\end{array}$ & abdominal surgery. & $\begin{array}{l}\text { urinary catheter removal Group B }(n=102) \text { : } \\
\text { without antibiotic prophylaxis }\end{array}$ & $\begin{array}{l}\text { absolute risk reduction } 16.7 \% \text {. the } \\
\text { relative risk reduction } 77.5 \% \text {. }\end{array}$ & $\begin{array}{l}\text { urinary tract infections and } \\
\text { bacteriuria in patients undergoing } \\
\text { abdominal surgery with } \\
\text { perioperative transurethral urinary } \\
\text { catheters. }\end{array}$ \\
\hline $\begin{array}{l}\text { Dieter et al., } \\
2014[46]\end{array}$ & RCT & $\begin{array}{l}\text { To evaluate whether nitrofurantoin } \\
\text { prophylaxis prevents } \\
\text { postoperative urinary tract } \\
\text { infection (UTI) in patients receiving } \\
\text { transurethral catheterization after } \\
\text { pelvic reconstructive surgery. }\end{array}$ & $\begin{array}{l}\text { participants undergoing pelvic } \\
\text { reconstructive surgery were } \\
\text { randomized }\end{array}$ & $\begin{array}{l}\text { Two groups were randomized during } \\
\text { catheterization: Group A } 81 \text { patients): } 100 \\
\text { mg nitrofurantoin once daily during } \\
\text { catheterization Group B (78 patients): placebo } \\
\text { was given once daily during catheterization. }\end{array}$ & $\begin{array}{l}22 \% \text { UTI with nitrofurantoin } 13 \% \text { UTI } \\
\text { with placebo RR 1.73, 95\% C1 0.85-3.52, } \\
P=12\end{array}$ & $\begin{array}{l}\text { Prophylaxis with daily nitrofurantoin } \\
\text { during catheterization does not } \\
\text { reduce the risk of postoperative UTI } \\
\text { in patients receiving short-term } \\
\text { transurethral catheterization after } \\
\text { pelvic reconstructive surgery. }\end{array}$ \\
\hline $\begin{array}{l}\text { Marschall et al., } \\
2013[47]\end{array}$ & $\begin{array}{l}\text { SR and MA RCT } \\
\text { and non-RCT }\end{array}$ & $\begin{array}{l}\text { To clarify whether antibiotic } \\
\text { prophylaxis at the time of urinary } \\
\text { catheter removal confers a benefit } \\
\text { in terms of preventing subsequent } \\
\text { symptomatic urinary tract } \\
\text { infections. }\end{array}$ & $\begin{array}{l}\text { All adults requiring short-term } \\
\text { urinary urethral and supra- } \\
\text { pubic catheterisation (up to and } \\
\text { including } 14 \text { days) in hospital }\end{array}$ & $\begin{array}{l}\text { A: antibiotic prophylaxis B: no antibiotic } \\
\text { prophylaxis }\end{array}$ & $\begin{array}{l}\text { Antibiotic prophylaxis was associated with } \\
\text { benefit to the patient, with an absolute } \\
\text { reduction in risk of urinary tract infection } \\
\text { of } 5.8 \% \text { between intervention and control } \\
\text { groups. The risk ratio was } 0.45(95 \% \\
\text { confidence interval } 0.28 \text { to } 0.72 \text { ). The } \\
\text { number needed to treat to prevent one } \\
\text { urinary tract infection was } 17 \text { (Confidence } \\
\text { interval } 12 \text { to } 30 \text { ). }\end{array}$ & $\begin{array}{l}\text { Patients admitted to hospitals who } \\
\text { undergo short term urinary } \\
\text { catheterization might benefit trom } \\
\text { antimicrobial prophylaxis when the } \\
\text { catheter is removed as they } \\
\text { experience fewer subsequent } \\
\text { urinary tract infections. Potential } \\
\text { disadvantages of more widespread } \\
\text { antimicrobial prophylaxis (side } \\
\text { effects and cost of antibiotics, } \\
\text { development of antimicrobial } \\
\text { resistance) might be mitigated by } \\
\text { the identification of which patients } \\
\text { are most likely to benefit trom this } \\
\text { approach. }\end{array}$ \\
\hline $\begin{array}{l}\text { Van Hees et al., } \\
2011[48]\end{array}$ & RCT & $\begin{array}{l}\text { investigated the effects of a single } \\
\text { dose antibiotic regimen, before } \\
\text { removing urinary catheters, on the } \\
\text { occurrence of significant } \\
\text { bacteriuria (SBU) and UTI. }\end{array}$ & $\begin{array}{l}\text { Patients scheduled to undergo } \\
\text { major surgery, such as an } \\
\text { abdominal operation or hip } \\
\text { surgery }\end{array}$ & $\begin{array}{l}\text { Group A: co-trimoxazole }(960 \mathrm{mg})(n=46) \\
\text { Group B: ciprofloxacin }(500 \mathrm{mg})(\mathrm{n}=43) \\
\text { Group C: placebo }(\mathrm{n}=51) \text { The three } \\
\text { groups were administered } 2 \text { hours before } \\
\text { catheter removal }\end{array}$ & $\begin{array}{l}\text { Symptomatic UTl incidence (\%): A: 1/31 } \\
\text { (3\%) B: 0/24 (0\%) C: 1/36 (3\%) }\end{array}$ & $\begin{array}{l}\text { our results do not support antibiotic } \\
\text { prophylaxis for urinary catheter } \\
\text { removal in non-genitourinary } \\
\text { surgical patients. }\end{array}$ \\
\hline $\begin{array}{l}\text { Berrondo et al., } \\
2018[49]\end{array}$ & RCT & $\begin{array}{l}\text { To evaluate the role of antibiotic } \\
\text { prophylaxis with oral ciprofloxacin } \\
\text { prior to urinary catheter removal } \\
\text { after radical prostatectomy in } \\
\text { preventing urinary tract infection } \\
\text { (UTI). }\end{array}$ & $\begin{array}{l}\text { Patients undergoing radical } \\
\text { prostatectomy. One hundred } \\
\text { seventy-five patients were } \\
\text { enrolled }\end{array}$ & $\begin{array}{l}\text { Group A: antibiotic prophylaxis group (2 doses } \\
\text { of oral ciproflloxacin prior to } \\
\text { urinary catheter removal) Group B: control } \\
\text { group (no antibiotics given prior to } \\
\text { urinary catheter removal) }\end{array}$ & $\begin{array}{l}\text { Eighteen patients }(7.41 \%) \text { in the } \\
\text { experimental group and } 19 \text { in the control } \\
(7.72 \%) \text { group had a symptomatic UTI } \\
\text { (odds ratio [OR] } 0.96[0.49-1.87]) \text {. }\end{array}$ & $\begin{array}{l}\text { In this prospective, randomized, } \\
\text { controlled trial, the use of antibiotic } \\
\text { prophylaxis with oral ciproflloxacin } \\
\text { prior to urinary catheter removal } \\
\text { after radical prostatectomy did not } \\
\text { decrease the rate of UTI and was } \\
\text { not associated with an increased } \\
\text { incidence of C diff enterocolitis. }\end{array}$ \\
\hline $\begin{array}{l}\text { Foxman et al, } 2015 \\
\text { [50] }\end{array}$ & Бт & $\begin{array}{l}\text { To test the therapeutic efficacy of } \\
\text { cranberry juice capsules in } \\
\text { preventing UTI post-surgery. }\end{array}$ & $\begin{array}{l}\text { Women with } \\
\text { elective gynecologic surgery }\end{array}$ & $\begin{array}{l}\text { Group A: cranberry capsules two times a day, } \\
\text { for } 6 \text { weeks postoperatively Group B: } \\
\text { placebo capsules All study participants } \\
\text { received a prophylactic intravenous antibiotic } \\
\text { administration preoperatively, including urinary } \\
\text { catheter insertion (as per hospital protocol). }\end{array}$ & $\begin{array}{l}\text { The occurrence of UTI \%: A: } 15 / 80=19 \% \\
\text { B: 30/80 =38\%; OR=0.42; 95\% Cl: 0.18, } \\
0.94 \quad \mathrm{p}=0.008\end{array}$ & $\begin{array}{l}\text { Among women undergoing elective } \\
\text { benign gynecologic surgery } \\
\text { involving urinary catheterization, } \\
\text { the use of cranberry extract tablets } \\
\text { during the postoperative period } \\
\text { reduced the rate of UTI by half. }\end{array}$ \\
\hline $\begin{array}{l}\text { Gunnarsson et } \\
\text { al., } 2017 \text { [51] }\end{array}$ & RCT & $\begin{array}{l}\text { to investigate whether intake of } \\
\text { cranberry juice concentrates pre- } \\
\text { operatively decreases the } \\
\text { incidence of postoperative UTIs in } \\
\text { hip fracture patients that received } \\
\text { a urinary catheter. }\end{array}$ & $\begin{array}{l}227 \text { Female patients } 60 \text { years and } \\
\text { older, with hip fractures. }\end{array}$ & $\begin{array}{l}\text { Group A ( } n=50 \text { ): two capsules of } 550 \mathrm{mg} \text { of } \\
\text { cranberry powder. Group } \mathrm{B}(\mathrm{n}=61 \text { ): placebo } \\
\text { capsules. Both groups receive the capsules } \\
\text { daily, from admission, until } 5 \text { days } \\
\text { postoperatively. Urine cultures were obtained } \\
\text { at admission, } 5 \text { and } 14 \text { days postoperatively. In } \\
\text { addition, Euro Qual five Dimensions } \\
\text { assessments were performed and patients were } \\
\text { screened for UTI symptoms. }\end{array}$ & $\begin{array}{l}\text { Number of patients with positive culture at } \\
\text { either day } 5 \text { or day } 14 \text { postoperatively: } \\
\text { A: } 19 / 50=(38 \%) \mathrm{B}: 23 / 61=(38 \%) \quad(\mathrm{p}=0.975 \text {, } \\
\text { RR } 0.988,95 \% \mathrm{Cl} 0.457-2.135)\end{array}$ & $\begin{array}{l}\text { Cranberry concentrate does not } \\
\text { seem to effectively prevent UTIs in } \\
\text { female patients with hip fracture } \\
\text { and indwelling urinary catheters. }\end{array}$ \\
\hline $\begin{array}{l}\text { Niel-Weise et al., } \\
2005[52]\end{array}$ & $\begin{array}{l}\text { SR Cochrane and } \\
\text { quasi-RCTs }\end{array}$ & $\begin{array}{l}\text { To determine if certain antibiotic } \\
\text { policies are better than others in } \\
\text { terms of prevention of urinary tract } \\
\text { infections, complications, quality } \\
\text { of life and cost effectiveness in } \\
\text { short term catheterised adults. }\end{array}$ & $\begin{array}{l}\text { All adults requiring short-term } \\
\text { urethral catheterization (up to and } \\
\text { including } 14 \text { days) in hospital for } \\
\text { urine monitoring, investigations, } \\
\text { acute retention problems, acute } \\
\text { incontinence problems and after } \\
\text { surgery. These include those } \\
\text { suffering from general medical } \\
\text { problems, acute illness, urinary } \\
\text { retention and following surgery. }\end{array}$ & $\begin{array}{l}\text { The interventions considered were: antibiotic } \\
\text { prophylaxis (continuous use), use of antibiotics if } \\
\text { clinically indicated (e.g. pain, fever) and use of } \\
\text { antibiotics if microbiologically indicated (growth } \\
\text { of bacteria from a specimen of urine in the } \\
\text { absence of clinical symptoms, the density of } \\
\text { bacteria taken as positive as defined by the } \\
\text { trialists). }\end{array}$ & $\begin{array}{l}\text { Only one trial focused on symptomatic } \\
\text { urinary tract infection. It showed a } \\
\text { significantly lower rate in the group } \\
\text { receiving prophylactic antibiotics, but the } \\
\text { observation was based on only } 16 \text { cases } \\
\text { of infection (RR } 0.20,95 \% \mathrm{Cl} 0.06 \text { to } 0.66 \text {, } \\
\text { Comparison } 01.01 \text { ). }\end{array}$ & $\begin{array}{l}\text { There was weak evidence that } \\
\text { antibiotic prophylaxis compared to } \\
\text { giving antibiotics when clinically } \\
\text { indicated reduced the rate of } \\
\text { symptomatic urinary tract infection } \\
\text { in female patients with abdominal } \\
\text { surgery and a urethral catheter for } \\
24 \text { hours. The limited } \\
\text { evidence indicated that receiving } \\
\text { antibiotics during the first three } \\
\text { postoperative days or from } \\
\text { postoperative day two } \\
\text { until catheter removal reduced the } \\
\text { rate of bacteriuria and other signs } \\
\text { of infection such as pyuria and } \\
\text { gram-negative isolates } \\
\text { in patients urine in surgical patients } \\
\text { with bladder drainage for at least } 24 \\
\text { hours postoperatively. There was } \\
\text { also limited evidence that }\end{array}$ \\
\hline
\end{tabular}




\section{Cureus}

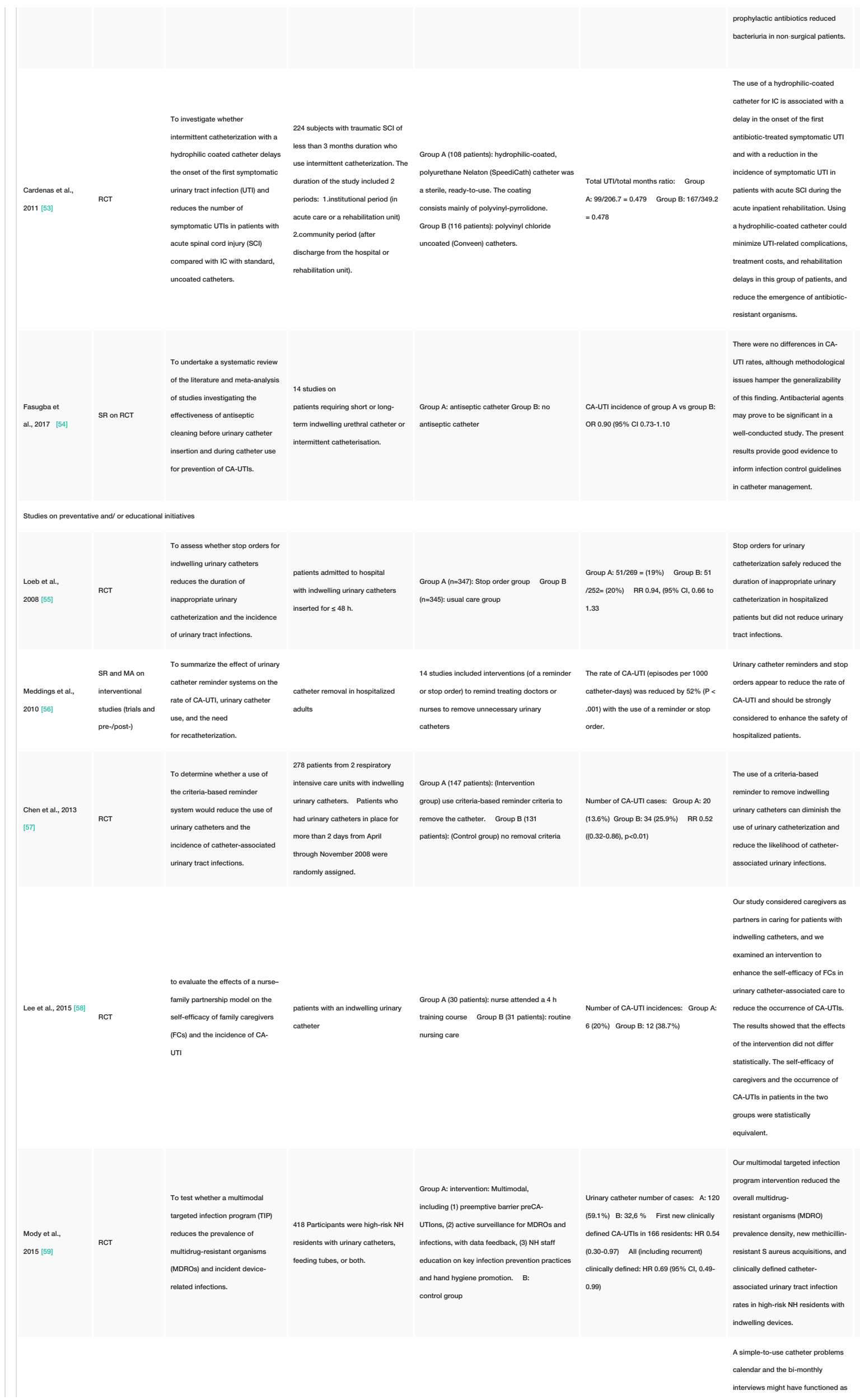




\section{Cureus}

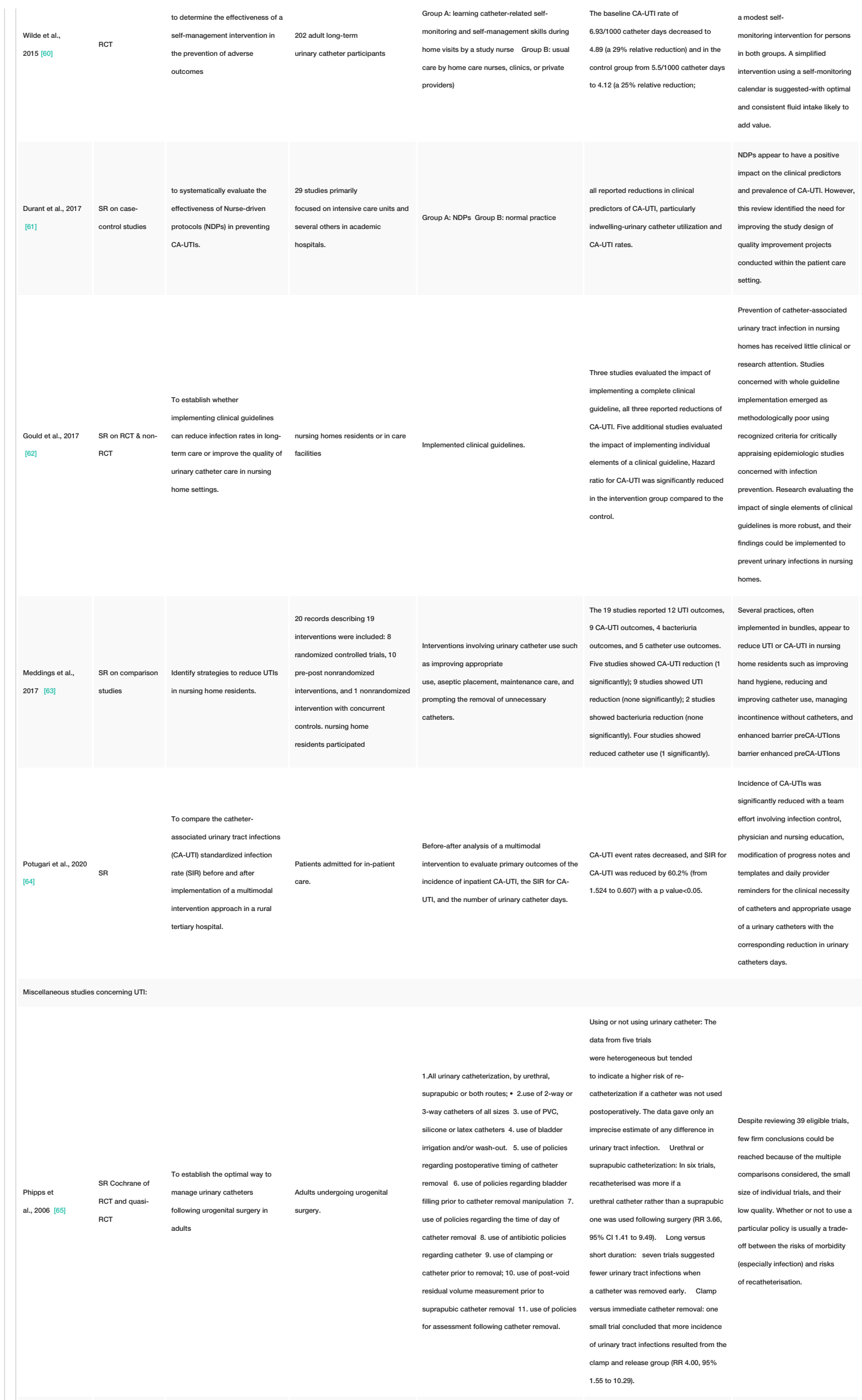




\section{Cureus}

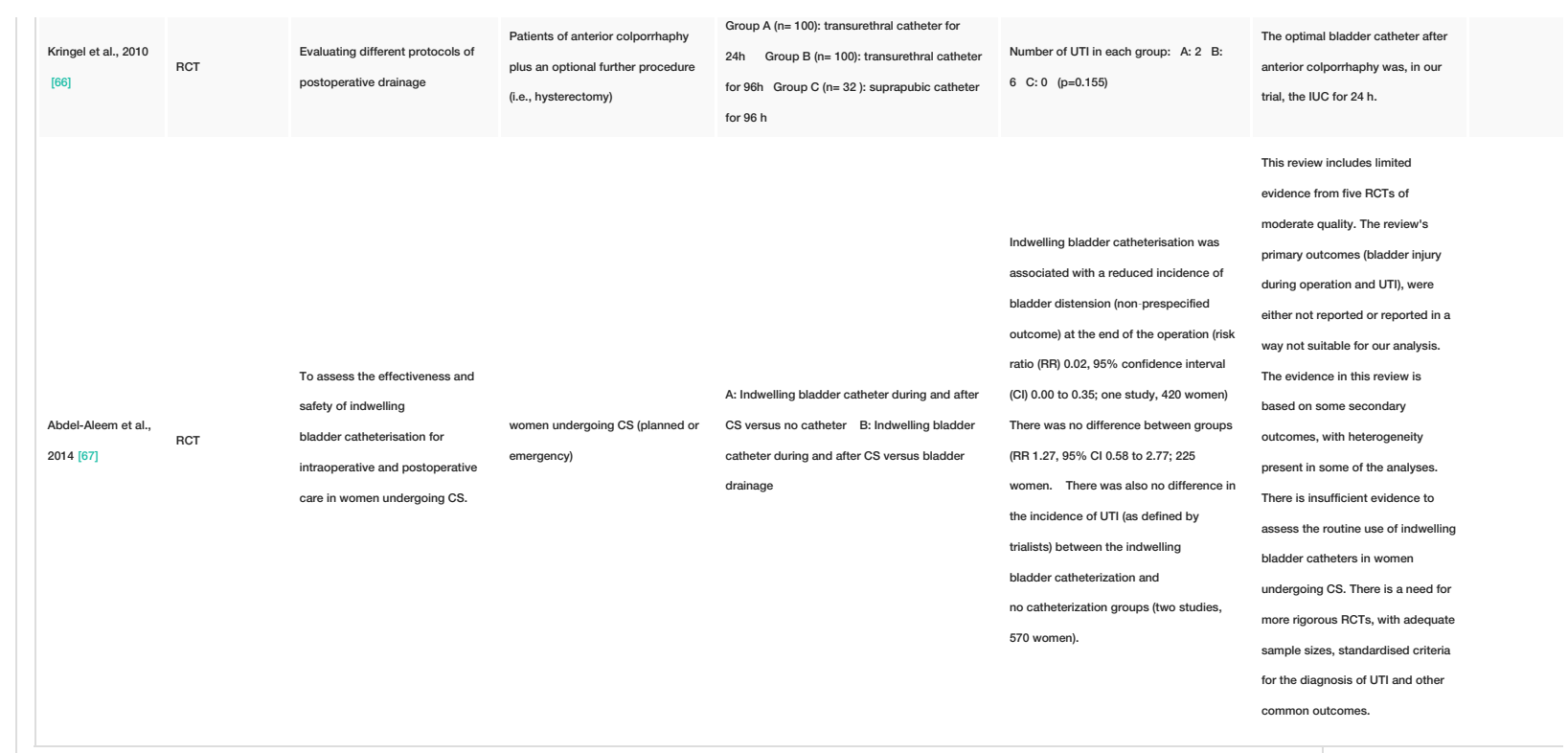

TABLE 1: Summary of Catheter-associated UTIs related reviews/randomized controlled trials

Abbreviations: UTI: urinary tract infection. CA-UTI: catheter-associated urinary tract infection. RCT: randomized controlled trial. S: systematic review. MA: metanalysis. n: number of patients. RR: risk ratio. OR: odds ratio. HR hazard ratio. p: p-value. Cl: confidence interval.

\section{Route of administration and catheterization selection type}

Comparing Intermittent Catheterization \& Short-term Indwelling Catheters?

Two RCTs $[9,10]$ and two SR $[11,12]$ were identified in which intermittent (self-) catheterization was compared with the use of temporary indwelling catheters. Including the 182 patients who underwent hip fracture or hip replacement surgery that Hälleberg Nyman et al. included; The absolute risk difference of CAUTI in the intermittent catheterization group was a low $2.4 \%$ with a Confidence interval of 6.9 to $11.6 \%$, a statistically insignificant difference ( 8 out of 85 patients (9.4\%) with CA-UTI in the intermittently catheterized group, compared to 10 out of 85 patients (11.8) with indwelling catheters [10]. When comparing transurethral indwelling with intermittent catheters, Hakvoort et al. reported a $(\mathrm{p}=0.03)$ lower CA-UTI rate with intermittent catheterization (12\% rate) compared to an indwelling catheter $(33 \%)$ left in place for seventy-two hours [9].

Nine RCTs with 1771 patients were included in a meta-analysis by Zhang et al. There was no significant difference in the rate of UTIs between indwelling catheterization and intermittent catheterization groups (RR: $1.23 ; \mathrm{CI} 95 \%[0.85 ; 1.76], \mathrm{P}>0.05$ ). At the same time, Hunter et al. concluded that the evidence was equivocal for symptomatic urinary tract infection [11].

\section{Comparing Temporary Transurethral to Suprapubic Catheterization}

Two RCTs compared the use of transurethral and suprapubic catheterization in patients who required urological interventions; suprapubic catheterization was comparable to transurethral catheterization with little to no difference in the rate of infection $[13,14]$. Two SRs $[12,15]$ and one Cochrane review [16] were also identified. When comparing suprapubic to urethral, all revealed that there is no statistically significant difference in the rates of CA-UTI. In a systematic review and meta-analysis (included twelve RCTs) by Healy et al., suprapubic catheterization was associated with a significant reduction in postoperative UTIs ( $20 \%$; OR: $0.31 ; 95 \%$ CI, $0.185-0.512 ; \mathrm{p}<0.01$ ) compared to $31 \%$ for urethral catheterization in the selected gynecologic patients [15]. Patients are three times more likely to develop a UTI with a transurethral catheter than a suprapubic catheter. Although Healy pointed out the increased noninfectious complication rate that suprapubic catheter was associated with (29\% compared to $11 \%$; OR: 4.14 ; $95 \%$ CI, $1.33-12.9$; $p=0.01$ ), those were tube malfunction related with no visceral injuries reported among the 1,300 participants [15].

Hunter et al. identified studies comparing suprapubic catheterization to various other methods of chronic bladder emptying, such as intermittent or indwelling urethral catheterization in the adult population [12]. Their review focused on suprapubic catheters, with the available evidence of 14 studies (one prospective non-randomized study and eight retrospective reviews with a comparator, a case-series, and qualitative assessments of quality of life) reported no significant difference between symptomatic CA-UTI outcomes between suprapubic and urethral catheters. However, the evidence is limited by the varied UTI criteria defined in their outcomes. The study revealed that suprapubic catheterization was associated with a lower incidence of urethral complications. However, the incidence of upper and lower urinary tract complications between urethral and suprapubic catheters was similar [12]. Similarly, a Cochrane review by Kidd et al. found an insufficient difference in symptomatic UTI risk between the suprapubic versus indwelling urethral catheters, but the suprapubic catheter group were catheterized for a longer duration than the urethral group (RR: $1.01 ;[0.61 ; 1.69])[16]$.

However, a Cochrane systematic review comparing short-term indwelling urethral catheters to suprapubic catheters found that indwelling catheterizations lead to more incidents of bacteriuria (RR 2.6, 95\% CI 2.12, 
3.18) and patient discomfort (RR 2.98; 95\% CI 2.31, 3.85)[52].

Fixation with a Catheter Securing Device (StatLock ${ }^{\circledR}$ ) or Valve

Only one review devoted to reviewing the evidence on the effect of catheter valves compared to free drainage into a bag for patients with indwelling urinary catheter [18]. While two RCT were evaluated by Van den Eijkel et al., results relating to CA-UTI were only reported in a single RCT; $60 \%$ of the intervention group with the valve developed CA-UTI, compared to $68 \%$ in the control group. The absolute differential in the infection rates of the two groups was statistically insignificant, with a $p=0.286$ [17].

An RCT conducted by Darouiche et al. investigated the effect of the StatLock ${ }^{\circledR}$ system, a fixation device for indwelling catheters was used in adult patients with neurogenic bladder due to spinal cord injury. Out of the 118 patients, among the 60 patients who received StatLock, the rate of CA-UTI was $45 \%$ lower, but a statistically insignificant association with increased UTI rates was established (RR: $0.55 ;[0.25 ; 1.22])[18]$.

Bladder Clamping and Free Urinary Drainage

One RCT [19] and three SRs [20,21,65] evaluated the necessity of bladder clamping before removing a urinary catheter. The RCT by Gong et al. did not report any statistically significant difference between the two groups (CA-UTI in the clamping group was $22.9 \%$ vs $20.3 \%$ for the controlled group). Wang et al. revealed no statistically significant difference between clamping and free drainage. There was no significant difference between clamping and unclamping groups found across four studies included in their study (OR $0.76,95 \% \mathrm{CI}(0.33,1.73))$. Gong et al. and Wang et al. concluded no significant difference between the clamping and unclamping groups in the outcomes of UTI and patients bladder function [19,21].

Fernandez et al. [20] delineated and compared three timepoints of catheter management as follows: (Group A) within 24 hours removal after free drainage, (Group B) within 72 hours removal, (Group C) within 24 hours removal in addition to bladder re-education. No significant differences were reported in the rates of CA-UTI in the 24 hours group (RR: $1.12[0.24 ; 5.18]$ ) or in the 72 hours group (RR: $0.55 ;[0.15 ; 2.01]$ ). There was no statistically significant difference in the UTI rates for clamping compared to free drainage for 24 or 72 hours before catheterization removal. In contrast, a Cochrane review that included one study favoured free immediate catheter removal with RR $4.00(1.55,10.29)[20]$.

\section{Duration of catheterization and minimizing dwell time}

The time a catheter is in place for a particular time associated with operative gynaecological interventions was studied in seven RCTs [22-28]. The catheters in the trials were either immediately removed postoperative or within 24 hours in the following RCTs [22-25]. While Bray et al. set the catheter removal 48 to 72 hours after as the prerequisite criteria to their intervention, Weemhoff et al. compared catheterization duration of two vs five days and its association with temporary catheter replacements, temporary catheter replacements and fewer urinary tract infections, and shorter hospital stays [27,28]. The seven authors of the selected RCTs concluded that the policy of short term catheterization compared to immediate or long term catheterization was associated with lower symptomatic urinary tract infection rates and less rate of recatheterization. All agreed that short term catheterization is also associated with earlier postoperative ambulation. However, all the studies but Chai et al. did not report lower rates of CA-UTI [24]. Moreover, contrary to the data above by the other authors, Liang et al. concluded that short term indwelling catheterization increased the incidence of UTI [30].

Phipps et al. conducted a Cochrane systematic review dealing with transurethral and suprapubic catheterization focusing on the following durations of catheterization: one vs. two days (one study: RR: $0.52 ;[0.05 ; 5.40]$ ), one vs. three days (three un-pooled studies [RR: $0.11 ;(0.03 ; 0.43)]$ ), one day vs. five days (two un-pooled studies, RRs 0.11 [0.03, 0.43]; 0.70 [ $0.29,1.67]$ ), and one vs. 14 days (one study, RR 0.21 $[0.03,1.65]$ [ [65]. Out of the 11 trials, seven trials with data suggested fewer urinary tract infections when a catheter was removed earlier. Although the studies did not indicate any statistical significance in the confidence interval of CA-UTI incidences, the point estimators conclusively indicated that the shorter duration resulted in the overall better outcome [65].

Fernandez et al. was the one study that purely focused on the duration and set different catheterization durations before the removal of short-term indwelling urethral catheters [30]. Four trials out of the eight showed no significant differences in CA-UTI rates in patient outcome after TURP (RR 0.55, 95\% CI 0.30 to 1.03). A statistically significant difference in CA-UTI rate was reported in one RCT that compared catheterization for 1 vs 5 days after rectal resection. The five-day rate was almost as twice as higher as the one-day indwelling catheterization [30]. Similarly, Phipps et al. suggested fewer urinary tract infections occur when a catheter is removed earlier (for example, 1 vs 3 days, RR $0.50,95 \%$ CI 0.29 to 0.87 ) [65].

It is worth noting that both the Lam et al. and Lusardi et al. reviews evaluated the expected duration of internal bladder catheters for up to 14 days. Whether they including a large number of interventions to be evaluated affected the calculated incidence rate of urinary tract infection in their studies or not remains to be unknown $[38,39]$.

\section{Assessing indication/necessity for catheterization}

Li et al. suggested that the routine use of indwelling urinary catheters for caesarean delivery is not necessary and is associated with fewer UTIs and no increase in postoperative adverse urinary events (relative risk [RR] of urinary tract infection compared with the use of indwelling urinary catheters, the non-catheterized patients had a significantly lower incidence of UTIs [RR 0.08; with 95\% confidence interval 0.01, 0.64 (study design: RCT); the RR in the single NCRT was 0.10 with $95 \%$ CI $0.02,0.57]$ [37].

Regarding the incidence of UTIs in another cesarean-related study, Nasr et al. found no statistically significant difference $(\mathrm{P}<0.001)$ between the catheterized and non-catheterized patients regarding UTI symptoms. The incidence of UTIs was $5.7 \%$ in the catheterized group for the $24 \mathrm{~h}$ postoperative and $2.9 \%$ for 
the one week postoperative, vs $0.5 \%(\mathrm{P}<0.001) 24$ h postoperative and $0 \%(\mathrm{P}<0.001)$ one week after the operation in the non-catheterized [36].

\section{Maintenance and care of catheterized patients}

Cleansing or Disinfection of the External Urethral Orifice

A network meta-analysis by Ercole et al. summarized data from thirty-three studies with seven different methods of urethral cleaning versus disinfection of the external urethral orifice was included (normal saline vs tap water vs soapy water vs antibacterial vs iodine vs chlorhexidine) [31]. No evidence of heterogeneity $(\mathrm{P}>0.05)$ was observed among the studies. The results showed no statistical difference in the incidence of CA-UTIs ( $P>0.05$ for all) when analyzing the different urethral cleaning methods versus disinfection [31].

Cao et al., through twenty-eight RCTs and nine SRs, that they included in their review, presents that the rate of urinary tract infection is not predicated on whether the perineum is cleaned with or without sterile water, or with the use of the povidone-iodine solution or chlorhexidine, or even with the use of clean or sterile technique, no difference in the incidence of CA-UTIs when comparing the different urethral cleaning methods versus disinfection ( $\mathrm{P}>0.05$ for all), this was postulated based upon thirty-three trials including 6390 patients with seven different urethral cleanings versus disinfection methods [32]. Similarly, studies that, prior to intermittent or indwelling catheterization, used anti-septic or non-medicated agents to clean peri-urethral or meatal areas showed no statistical significance in reducing its association with the incidence rate of UTI [33].

It was suggested that cleaning the peri-urethral area before catheter insertion can be undertaken, nonsterile water would be an equally weighted option, and the economical alternative as its effectiveness compared to the sterile water. Anti-septic solutions (chlorhexidine and PVP-I) were as equal. More studies about UTI development and saved expenditure on costs were not looked at and needed to be confirmed [3133].

Even though a consistent level of hygiene was scrutinized with short-term catheter use in their RCT, Fasugba et al. failed to result in a substantial reduction in CA-UTI rates for long-term catheterization [54].

Irrigations and Washouts

The practice of irrigating long-term indwelling urinary catheters has also been assessed by two systematic reviews [34,35], including reports of various solutions and regimens. One of the RCTs in a dedicated RCT conducted by Shepherd et al. [35]. Four trials studied the following: (any washout vs no washout, saline washout versus no washout, citric acid washout versus no washout). The authors were uncertain if comparing washout and no washout had any significant effect on the rate of symptomatic UTI or duration of catheterization in situ. The evidence was not adequate to conclude if washouts were beneficial or harmful due to the poor methodological quality and reporting [35].

Both Systematic reviews have five studies that were labelled to be of poor quality and concluded inconclusive effective at either reducing symptomatic CA-UTIs or duration of first catheter change [34,35].

\section{Prophylactic measures}

Antiseptic-coated Compared to Standard Non-septic Catheters

Lam, Pickard, Bonfill, and Jahn, most notably, from the studies we included, compared the effect of antiseptic catheter surfaces vs the non-septic catheters, respectively [38,40-42]. Two Cochrane reviews conducted by Lam et al. and Jahn et al. have not revealed any advantageous benefits of silver-coated catheters over the standard one (4241 patients; RR: $0.99 ;[0.85 ; 1.16])$ and (20 patients; RR: $10 ;[0.83 ; 1.2])$ respectively [38,42]. Jahn et al. concluded evidence should not be treated as a reliable basis for practical implications due to the small sample of the trials and that very few trials have compared several types of catheters for long-term bladder drainage [42].

While Lam et al. [38] concluded that the antiseptic-coated catheters resulted in no statistically significant reduction in symptomatic CA-UTI and was considerably expensive, Pickard'sPickard's 2012 RCT further stated that silver alloy-impregnated catheters might be less cost-effective than the antibiotic (Nitrofurazone) coated with OR 0.96 ( 0.78 to 1.19 ); $\mathrm{p}=0.69$ compared to OR 0.81 ( 0.65 to 1.01 ) $\mathrm{p}=0.031$, respectively [40].

There is no unequivocal evidence supporting the use of either anti-septic, or antimicrobial coated catheters is more beneficial than using standard catheters in reducing UTI in patients who require long term catheterization, no sufficient data to decide which type is the go-to for CA-UTI prevention [41,42].

Antiseptic-coated Compared to Antibiotic-impregnated

One large trial included in a Cochrane review SR from 2014 compared silver alloy-coated (antiseptic-coated) catheters versus antimicrobial-coated (nitrofurazone) catheters; they suggested an advantage of antisepticimpregnated catheters over nitrofural-impregnated catheters (one study; 4250 patients; RR: 0.84; [071; 1.00]) [38]. The results showed that people were less likely to have asymptomatic CA-UTI with nitrofurazone-impregnated (228 in 2153 patients, 10.6\%) than silver alloy-coated (263 in 2097 patients $12.5 \%)$. However, the magnitude of reduction was not statistically significant and hence may not be clinically important (RR $0.84,95 \%$ CI 0.71 to 1.00 ) [38].

Beattie et al. emphasized that the heterogeneity was too significant for them to calculate an estimate for all studies combined but stated that there was nothing to suggest that one approach was better than the other [43]. The low number of participants, wide confidence intervals and risk of systematic errors and biases 
in one of the studies means that the methodological quality should be considered to be a low one, and cannot conclude if whether silver-alloy urinary catheters reduce CA-UTI compared with standard silicon or latex urinary catheters [43].

Antibiotic-related Prophylaxis

Either comparing prophylactic antibiotic administration with no antibiotic prophylaxis or using antibioticimpregnated catheters were discussed in eleven studies; five are RCTs [40,44-48], four are SRs [38,39,47,52], and four Cochrane Database SRs [38,39,43,52]. In one trial, conducted by Niël-Weise et al., in comparing antibiotic prophylaxis with antibiotics administration when clinically indicated in the female surgical patients who had a urethral catheter for more than 24 hours, symptomatic UTI was less frequent in the prophylaxis group (RR 0.20, 95\% CI 0.06 to 0.66) [52]. Likewise, Berrondo et al., in their prospective, randomized, controlled trial, using antibiotic prophylaxis with oral ciprofloxacin before urinary catheter removal after radical prostatectomy did not decrease UTI rate [49].

Moreover, in adults requiring short-term urinary urethral and supra-pubic catheterization up to and including 14 days, the patients who received the following systemic antibiotic prophylaxis (cefotaxime, trimethoprim/sulfamethoxazole, ciprofloxacin, or Nitrofurantoin) antibiotic prophylaxis was associated with an absolute reduction in risk of urinary tract infection of $5.8 \%$ with a risk ratio of 0.45 and a $95 \% \mathrm{CI}$ between 0.28 to 0.72 ) [47]. Marschall et al. reported a number needed to treat of 17 ( $95 \%$ confidence interval, 12 to 30 ) to prevent a single CA-UTI [47]. However, Van Hees et al. concluded that their results do not support antibiotic prophylaxis for urinary catheter removal in non-genitourinary surgical patients. Their study included patients who underwent surgery and received a single prophylactic antibiotic dose 2 hours before catheter removal (ciprofloxacin $500 \mathrm{mg}$ [n=43], co-trimoxazole $960 \mathrm{mg}[\mathrm{n}=46]$, placebo [ $\mathrm{n}=51]$ ) [48].

Lam et al. reported a significant difference in the use of nitrofural-impregnated catheters compared to standard catheters (one trial that included 4297 patients concluded a RR of 0.84 with a $95 \%$ confidence interval of $[0.71 ; 0.99])$ [38]. While Lusardi et al. for the systemic intravenous administration of trimethoprim/sulfamethoxazole (single trial; 90 patients; RR: 0.20; [0.06; 0.66]) [39].

Phytotherapeutic Cranberry Extracts

Both Foxman et al. and Gunnarsson et al. reviewed whether the prophylactic use of cranberry extract tablets during the postoperative period will reduce or even prevent the occurrence of CA-UTI [ 50,51$]$. In the study by Gunnarson et al., 227 female patients, aged 60 years and older, with hip fractures were randomized to either receive $550 \mathrm{mg}$ of cranberry powder three times daily or placebo capsules daily until five days postoperatively [51]. There was no difference between the groups of patients with postoperative positive urine cultures at either day 5 or 14 days postoperatively $(p=0.975)$ : 13 of $33(39 \%)$ in the placebo group and 13 of $47(28 \%)$ in the cranberry group $(\mathrm{P}=0.270)$ had a positive urine culture. However, this difference was not statistically significant $(\mathrm{P}=0.270)[51]$.

Foxman et al. concluded that patients undergoing elective gynecologic surgery involving urinary catheterization, the use of cranberry tablets during the postoperative period reduced the rate of UTI by at least a half; 15 of 80 patients (19\%) for the intervention group in comparison to 30 of 80 patients (38\%) for the placebo group with positive urine culture; $(\mathrm{OR}=0.38 ; 95 \% \mathrm{CI}: 0.19,0.79 ; \mathrm{p}=0.008)$ [50].

\section{Educational Protocols \& Preventative Implementations}

Educational and raising patient awareness approaches were discussed in eleven studies, five SRs [56,61 64] and five RCTs [55,57-60]. Meddings et al., who reviewed catheter discontinuation strategies for hospitalized patients and pooled their results of 7 seven trials, reported that the "stop order" intervention to prompt removal of unnecessary catheters reduced the duration of catheters in place by 1.06 days, and the use of either "reminders or stop orders" decreased the CA-UTI rate by $53 \%$, (RR: 0.48 ; [0.28; 0.68]; p = 0.001) [56]. Another review of nineteen studies by Meddings et al. reported that CA-UTI decreased with compliance with hand hygiene protocols during urethral catheter administrations and any follow-up catheter cares [63]. While Wilde et al. determined in their study in the experimental group (learning catheter-related self-monitoring and self-management skills during home visits), the baseline CA-UTI rate of $6.93 / 1000$ catheter days decreased to 4.89 with a $29 \%$ relative reduction while in the control group from $5.5 / 1000$ catheter days to 4.12 with a $25 \%$ relative reduction [60].

Another systemic review by Mody et al. confirmed that the efficacy of implementing preventive protocols in nursing homes did reduce the catheter-associated UTI rates decreased from 6.78 to 2.63 infections per 1000 catheter-days [59]. With use of the random-effects negative binomial regression models, the rates decreased from 6.42 to 3.33 (incidence rate ratio [IRR], 0.46; 95\% CI, 0.36-0.58; P . .001) [59]. This was the only intervention that demonstrated a statistically significant reduction in CA-UTI in chronically catheterized patients due to the implemented comprehensive program that limited antimicrobial use, improved hand hygiene, and promote standardized CA-UTI definitions and active drug-resistant organisms surveillance protocol [59].

\section{Miscellaneous \& Coupled Interventions}

One Cochrane review, following urogenital surgery in adults, examined seven trials that compared the postoperative duration of catheter use; these trials suggested that shorter-term catheterization was associated with fewer UTI incidences and more patients required re-catheterization following a urethral compared to a suprapubic catheter [65]. While Ercole et al. showed that the use of an intermittent catheter with clean technique results in low rates of complications or infections compared to the use of an indwelling catheter, in the same review, postoperative catheter removal up to 24 hours and the use of an antimicrobialimpregnated or hydrophilic-coated catheter resulted in lower urinary tract infection [31]. 


\section{Discussion}

We included fifty-nine combined studies, including thirty-six RCTs and twenty-three SRs, meant to shed light on more than fifty measures. Ten of these measures were studied. The bulk of the studies was published in the 2010 s period. Since we identified numerous studies with different evidence and measures regarding the prevention and management of CA-UTI in different patient groups and settings, the data regarding catheterization, duration, and prophylactic measure are clinically heterogeneous states of the evidence not conclusive. Although several review authors have identified a couple of studies for some interventions, they could not perform meta-analyses due to the highly heterogeneous finding between the included studies. Three contributing factors for the resulted heterogeneity might be as follows:

\section{Study Groups}

The patient groups that were compared varied from one study to the other. Patients with different diagnoses, anatomies and health/immunological status may have different preconditions and predispositions to infections, which in turn makes it harder to combine and group studies to obtain enough participants with similar physical and immunological conditions in comparison to be able to report an efficient data for the prevention of catheter-associated urinary tract infections.

Interventions

Different interventions lead to large variations in what was compared. Studies that were conducted before the first half of the first decade in the 2000s were excluded due to the fear that the applicability and practicality of their findings-in particular, relating to the guidelines related to administration of prophylactic antibiotics or types of education programs would not resonate nor translate to the current clinical practices; as the perception about prescribing practices and awareness around resistance may well have over the time. Therefore, to avoid the need to examine the preparations or methods used at the time in the study today or whether there have been other changes over the years, 2005 was agreed on.

Measurement of Outcome Measures

The terms Urinary tract infection, bacteriuria and catheter-associated urinary tract infection were loosely used and varied between the studies. Some studies have not even defined the criteria for their used outcome. Some studies used the terms CA-UTI and catheter-associated asymptomatic bacteriuria or catheterassociated bacteriuria interchangeably. Additionally, terms like Bacteriuria and UTI were differently defined. If we look at three publication as an example, definitions of urinary tract infection in those studies, for instance, were: > = $105 \mathrm{CFU} / \mathrm{ml}$ with > 10 leukocytes per $\mathrm{mm} 3$ of urine [38], >= $105 \mathrm{CFU} / \mathrm{ml}$ with one of the following symptoms: fever, pyuria, hematuria, chills, and/or dysreflexia [39], >= $105 \mathrm{CFU} / \mathrm{ml}$ [42].

All Catheter types are susceptible to biofilm formation and catheter encrustation; hence administering prophylactic antibiotics may delay the pathogenesis of CA-UTIs rather than preventing their occurrence. The use of low-dose, prophylactic antibiotics might aid in creating "persister" cells that are genetically capable of invading the uroepithelium and result in infection and integration with urinary bladder microbiota. Therefore, contributing more to sepsis and infection [68].

The duration of a catheter is generally based on individual cases rather than evidence-based knowledge and therefore varies among clinical practice. In-dwelling catheters have been associated with positive urine cultures, which can subsequently lead to urinary tract infection can which, as a result, increases the duration of hospital stay, costs and risk of morbidity. The risk of developing a CA-UTI is related to catheter dwell time $[69,70]$. For catheterized patients, the rate of development of catheter-associated bacteriuria is between $3 \%$ to $7 \%$ per day $[71,72]$. The likelihood of bacteriuria approaches $100 \%$ if a patient has an indwelling urinary catheter for $\geqslant 30$ days $[73,74]$, which is part of the rationale for why a urine culture alone is not sufficient to diagnose a CA-UTI. While bacteriuria is a risk factor for UTI, the frequency of progression from bacteriuria to CA-UTI is low and treating ASB does not decrease the risk of future CA-UTI. Other risk factors for the development of CA-UTI include urinary tract instrumentation, diabetes mellitus, and malnutrition $[75,76]$. The two principal factors that lead to CA-UTIs are unnecessary urinary catheter placement and unacceptable delay in removing a catheter when it is no longer needed [77]. Unfortunately, $38 \%$ of attending physicians are unaware that their patients have a urinary catheter in place, which might be due to the ambiguity of catheter placement indication in approximately $30 \%$ of cases [78].

An analysis by Hutton et al. [79] showed that implementing their multimodal intervention program led to 8.7 fewer CA-UTIs and 2.9 fewer resident hospitalizations per nursing home per year. 120-bed NH would have program costs of $\$ 20,279$ /year. The cost of disease treatment would be reduced by $\$ 54,316$ per year, resulting in a net cost savings of $\$ 34,037$. A cost savings of $\$ 15,136$ in CA-UTI care and $\$ 39,180$ in-hospital care for CA-UTIs and CA-UTI-associated septicemia, for a total net savings of $\$ 34,037$ for the healthcare system. As well as 0.2 more QALYs (quality-adjusted life-years) than their control group.

Duszyńska et al. estimated the cost of HAIs in a Polish ICU to range from EUR 10,035 to 22,411 [80]. While in the USA, an estimate of 449,334 healthcare-associated catheter-associated urinary tract infections (CAUTIs) per year, associated with an additional cost of US\$749-10077-9 per admission in 2007 (or an estimated US $\$ 3744$ when complicated by blood septicemia) [77,81].

An Australian study revealed that staffing costs for infection prevention nurses exceed AUD 100million per year and that $36 \%$ of their time is spent on patient monitoring. Another study confirmed that those undertaking active surveillance on patients had never been trained, and skills like reporting data to hospital executives are either not appropriately done $[82,83]$. This means that much of the CA-UTI data being collected might not be a true reflection of the magnitude of catheter complications and makes it harder to analyze the infection rate in an efficient, productive manner. Saint et al. surveyed 719 acute-care American hospitals for their CA-UTI prevention protocols in 2005; more than $70 \%$ of the surveyed hospitals documented their rates of CA-UTI, $44 \%$ documented which patient had a urinary catheter inserted, and $26 \%$ documented the duration of catheterization. No widely accepted protocol to prevent CA-UTI was reported. 
$30 \%$ of the surveyed hospitals reported the regular use of antimicrobial catheters, $14 \%$ reported condom catheters in men, and a mere $9 \%$ used catheter reminders or stop-orders [84].

\section{Conclusions}

In terms of implications to clinical practice, the results of this review suggest that healthcare workers should think of 2 strategies to reduce rates of CA-UTI: limit catheter use and shorten the duration of catheterization. The literature also supports either daily scheduled reviews or stop orders to safely reduce the duration of inappropriate urinary catheterization in hospitalized patients. Based on the current state of evidence, there are insufficient data to determine whether transurethral or suprapubic routes are most appropriate for catheterization. The reduced morbidity rate of suprapubic catheterization is offset by higher rates of catheter-related complications and doesn't necessarily mean a shorter hospital stay. No good evidence exists to adequately conclude if washouts were beneficial or harmful due to poor methodological quality and the substantial risk of bias of the included studies. No significant difference was found between the clamping and unclamping groups. Given the scant state of evidence, procedures relating to clamping of indwelling urinary catheters should not be favoured over free drainage. No significant differences have been demonstrated among the various methods of cleansing or disinfecting the external urethral orifice. Evidence from studies that, before intermittent or indwelling catheterization, used either anti-septic or nonmedicated agents to clean peri-urethral or meatal area showed no statistical significance in reducing its association with the incidence rate of UTI. Evidence of antiseptically coated catheters, compared to standard uncoated catheters, is equivocal. Antibiotic-impregnated catheters seem to be more documented in the literature and reduce the rate of catheter-associated symptomatic urinary tract infection. The current evidence on phytotherapy using cranberry extracts to prevent UTIs remains debatable, in part due to the trials were small and methodological weaknesses were shown. Therefore, the evidence was not a reliable basis for any clinical conclusions. So, there is no well-justification in recommending it highly.

\section{Additional Information \\ Disclosures}

Conflicts of interest: In compliance with the ICMJE uniform disclosure form, all authors declare the following: Payment/services info: All authors have declared that no financial support was received from any organization for the submitted work. Financial relationships: All authors have declared that they have no financial relationships at present or within the previous three years with any organizations that might have an interest in the submitted work. Other relationships: All authors have declared that there are no other relationships or activities that could appear to have influenced the submitted work.

\section{References}

1. Smyth ET, McIlvenny G, Enstone JE, et al.: Four country healthcare associated infection prevalence survey 2006: overview of the results. J Hosp Infect. 2008, 69:230-48. 10.1016/j.jhin.2008.04.020

2. Saint S, Chenoweth CE: Biofilms and catheter-associated urinary tract infections. Infect Dis Clin North Am. 2003, 17:411-32. 10.1016/80891-5520(03)00011-4

3. Jain P, Parada JP, David A, et al.: Overuse of the indwelling urinary tract catheter in hospitalized medical patients. Arch Intern Med. 1995, 155:1425-1429. 10.1001/archinte.1995.00430130115012

4. Gould CV, Umscheid CA, Agarwal RK, Kuntz G, Pegues DA, HIPAC: Guideline for prevention of catheterassociated urinary tract infections 2009. Infect Control Hosp Epidemiol. 2010, 31:319-26. 10.1086/651091

5. Shuman EK, Chenoweth CE: Recognition and prevention of healthcare-associated urinary tract infections in the intensive care unit. Crit Care Med. 2010, 38:373-9. 10.1097/CCM.0b013e3181e6ce8f

6. Latour K, Jans B: The HALT management team (2009) Healthcare-associated infections in long-term care facilities. Results of the pilot point prevalence survey. The Scientific Institute of Public Health (WIV-ISP), Brussels; 2009.

7. Conway LJ, Pogorzelska M, Larson E, et al.: Adoption of policies to prevent catheter-associated urinary tract infections in United States intensive care units. Am J Infect Control. 2012, 40:705-10. 10.1016/j.ajic.2011.09.020

8. Page MJ, McKenzie JE, Bossuyt PM, et al.: The PRISMA 2020 statement: an updated guideline for reporting systematic reviews. BMJ. 2021, 372:71. 10.1136/bmj.n71

9. Hakvoort RA, Thijs SD, Bouwmeester FW, et al.: Comparing clean intermittent catheterisation and transurethral indwelling catheterisation for incomplete voiding after vaginal prolapse surgery: a multicentre randomised trial. BJOG. 2011, 118:1055-60. 10.1111/j.1471-0528.2011.02935.x

10. Nyman MH, Gustafsson M, Langius-Eklöf A, Johansson JE, Norlin R, Hagberg L: Intermittent versus indwelling urinary catheterisation in hip surgery patients: a randomised controlled trial with costeffectiveness analysis. Int J Nurs Stud. 2013, 50:1589-98. 10.1016/j.ijnurstu.2013.05.007

11. Zhang W, Liu A, Hu D, et al.: Indwelling versus intermittent urinary catheterization following total joint arthroplasty: a systematic review and meta-analysis. PLoS ONE. 2015, 10:e0130636. 10.1371/journal.pone.0130636

12. Hunter KF, Bharmal A, Moore KN: Long-term bladder drainage: suprapubic catheter versus other methods: a scoping review. Neurourol Urodyn. 2013, 32:944-51. 10.1002/nau.22356

13. Dixon L, Dolan LM, Brown K, Hilton P: RCT of urethral versus suprapubic catheterization . Br J Nurs. 2010, 19:S7-13. 10.12968/bjon.2010.19.Sup8.79063

14. Stekkinger E, van der Linden PJ: A comparison of suprapubic and transurethral catheterization on postoperative urinary retention after vaginal prolapse repair: a randomized controlled trial. Gynecol Obstet Invest. 2011, 72:109-16. 10.1159/000323827

15. Healy EF, Walsh CA, Cotter AM, Walsh SR: Suprapubic compared with transurethral bladder catheterization for gynecologic surgery: a systematic review and meta-analysis. Obstet Gynecol. 2012, 120:678-87. 10.1097/AOG.0b013e3182657fod

16. Kidd EA, Stewart F, Kassis NC, Hom E, Omar MI: Urethral (indwelling or intermittent) or suprapubic routes for short-term catheterisation in hospitalised adults. Cochrane Database Syst Rev. 2015, 10:1465-1858. 10.1002/14651858.CD004203.pub3

17. van den Eijkel E, Griffiths P: Catheter valves for indwelling urinary catheters: a systematic review . Br I Community Nurs. 2006, 11:111-114. 10.12968/bjcn.2006.11.3.20586

18. Darouiche RO, Goetz L, Kaldis T, Cerra-Stewart C, AlSharif A, Priebe M: Impact of StatLock securing device on symptomatic catheter-related urinary tract infection: a prospective, randomized, multicenter clinical trial. Am J Infect Control. 2006, 34:555-60. 10.1016/j.ajic.2006.03.010

19. Gong Y, Zhao L, Wang L, Wang F: The effect of clamping the indwelling urinary catheter before removal in cervical cancer patients after radical hysterectomy. J Clin Nurs. 2017, 26:1131-6. 10.1111/jocn.13579 
20. Fernandez RS, Griffiths RD: Clamping short-term indwelling catheters: a systematic review of the evidence . J Wound Ostomy Continence Nurs. 2005, 32:329-36. 10.1097/00152192-200509000-00012

21. Wang LH, Tsai MF, Han CS, Huang YC, Liu HE: Is bladder training by clamping before removal necessary for short-term indwelling urinary catheter inpatient? A systematic review and meta-analysis. Asian Nurs Res. 2016, 10:173-81. 10.1016/j.anr.2016.07.003

22. Alessandri F, Mistrangelo E, Lijoi D, Ferrero S, Ragni N: A prospective, randomized trial comparing immediate versus delayed catheter removal following hysterectomy. Acta Obstet Gynecol Scand. 2006, 85:716-20. 10.1080/00016340600606976

23. Sekhavat L, Farajkhoda T, Davar R: The effect of early removal of indwelling urinary catheter on postoperative urinary complications in anterior colporrhaphy surgery. Aust N Z J Obstet Gynaecol. 2008, 48:348-52. 10.1111/i.1479-828X.2008.00842.x

24. Chai J, Pun TC: A prospective randomized trial to compare immediate and 24-hour delayed catheter removal following total abdominal hysterectomy. Acta Obstet Gynecol Scand. 2011, 90:478-82. 10.1111/j.16000412.2011.01104.x

25. Ahmed MR, Sayed Ahmed WA, Atwa KA, Metwally L: Timing of urinary catheter removal after uncomplicated total abdominal hysterectomy: a prospective randomized trial. Eur J Obstet Gynecol Reprod Biol. 2014, 176:60-3. 10.1016/j.ejogrb.2014.02.038

26. El-Mazny A, El-Sharkawy M, Hassan A: A prospective randomized clinical trial comparing immediate versus delayed removal of urinary catheter following elective cesarean section. Eur J Obstet Gynecol Reprod Biol. 2014, 181:111-4. 10.1016/j.jogrb.2014.07.034

27. Bray R, Cartwright R, Digesu A, Fernando R, Khullar V: A randomised controlled trial comparing immediate versus delayed catheter removal following vaginal prolapse surgery. Eur J Obstet Gynecol Reprod Biol. 2017, 210:314-8. 10.1016/i.ejogrb.2017.01.015

28. Weemhoff M, Wassen MM, Korsten L, Serroyen J, Kampschöer PH, Roumen FJ: Postoperative catheterization after anterior colporrhaphy: 2 versus 5 days. A multicentre randomized controlled trial. Int Urogynecol J. 2011, 22:477-83. 10.1007/s00192-010-1304-0

29. Liang CC, Lee CL, Chang TC, et al.: Postoperative urinary outcomes in catheterized and non-catheterized patients undergoing laparoscopic-assisted vaginal hysterectomy-a randomized controlled trial. Int Urogynecol J Pelvic Floor Dysfunct. 2009, 20:295-300. 10.1007/s00192-008-0769-6

30. Fernandez RS, Griffiths RD: Duration of short-term indwelling catheters--a systematic review of the evidence. J Wound Ostomy Continence Nurs. 2006, 33:145-53; quiz 154-5. 10.1097/00152192-20060300000008

31. Ercole FF, Macieira TG, Wenceslau LC, Martins AR, Campos CC, Chianca TC: Integrative review: evidences on the practice of intermittent/indwelling urinary catheterization. Rev Lat Am Enfermagem. 2013, 21:45968. 10.1590/s0104-11692013000100023

32. Cao Y, Gong Z, Shan J, Gao Y: Comparison of the preventive effect of urethral cleaning versus disinfection for catheter-associated urinary tract infections in adults: A network meta-analysis. Int J Infect Dis. 2018, 76:102-8. 10.1016/j.ijid.2018.09.008

33. Cheung K, Leung P, Wong YC, et al.: Water versus antiseptic periurethral cleansing before catheterization among home care patients: a randomized controlled trial. Am J Infect Control. 2008, 36:375-80. 10.1016/j.ajic.2007.03.004

34. Sinclair L, Hagen S, Cross S: Washout policies in long-term indwelling urinary catheterization in adults: a short version cochrane review. Neurourol Urodyn. 2011, 30:1208-12. 10.1002/nau.21063

35. Shepherd AJ, Mackay WG, Hagen S: Washout policies in long-term indwelling urinary catheterisation in adults. Cochrane Database Syst Rev. 2017, 3:004012. 10.1002/14651858.CD004012.pub4

36. Nasr AM, ElBigawy AF, Abdelamid AE, Al-Khulaidi S, Al-Inany HG, Sayed EH: Evaluation of the use vs nonuse of urinary catheterization during cesarean delivery: a prospective, multicenter, randomized controlled trial. J Perinatol. 2009, 29:416-421. 10.1038/ip.2009.4

37. Li L, Wen J, Wang L, Li YP, Li Y: Is routine indwelling catheterisation of the bladder for caesarean section necessary? a systematic review. BJOG. 2011, 118:400-9. 10.1111/j.1471-0528.2010.02802.x

38. Lam TB, Omar MI, Fisher E, Gillies K, MacLennan S: Types of indwelling urethral catheters for short-term catheterisation in hospitalised adults. Cochrane Database Syst Rev. 2014, 9:CD004013. 10.1002/14651858.CD004013.pub4

39. Lusardi G, Lipp A, Shaw C: Antibiotic prophylaxis for short-term catheter bladder drainage in adults . Cochrane Database Syst Rev. 2013, 7:005428. 10.1002/14651858.CD005428.pub2

40. Pickard R, Lam T, Maclennan G, et al.: Types of urethral catheter for reducing symptomatic urinary tract infections in hospitalised adults requiring short-term catheterisation: multicentre randomised controlled trial and economic evaluation of antimicrobial- and antiseptic-impregnated urethral catheters (the CATHETER trial). Health Technol Assess. 2012, 16:1-197. 10.3310/hta16470

41. Bonfill X, Rigau D, Esteban-Fuertes M, et al.: Efficacy and safety of urinary catheters with silver alloy coating in patients with spinal cord injury: a multicentric pragmatic randomized controlled trial. the ESCALE trial. Spine J. 2017, 17:1650-7. 10.1016/j.spinee.2017.05.025

42. Jahn P, Beutner K, Langer G: Types of indwelling urinary catheters for long-term bladder drainage in adults Cochrane Database Syst Rev. 2012, 10:CD004997. 10.1002/14651858.CD004997.pub3

43. Beattie M, Taylor J: Silver alloy vs. uncoated urinary catheters: a systematic review of the literature . J Clin Nurs. 2011, 20:2098-108. 10.1111/j.1365-2702.2010.03561.x

44. Johnson JR, Kuskowski MA, Wilt TJ: Systematic review: antimicrobial urinary catheters to prevent catheterassociated urinary tract infection in hospitalized patients. Ann Intern Med. 2006, 144:116-26. 10.7326/0003 4819-144-2-200601170-00009

45. Pfefferkorn U, Lea S, Moldenhauer J, Peterli R, von Flüe M, Ackermann C: Antibiotic prophylaxis at urinary catheter removal prevents urinary tract infections: a prospective randomized trial. Ann Surg. 2009, 249:5735. 10.1097/SLA.0b013e31819a0315

46. Dieter AA, Amundsen CL, Edenfield AL, Kawasaki A, Levin PJ, Visco AG, Siddiqui NY: Oral antibiotics to prevent postoperative urinary tract infection: a randomized controlled trial. Obstet Gynecol. 2014, 123:96103. 10.1097/AOG.0000000000000024

47. Marschall J, Carpenter CR, Fowler S, Trautner BW: Antibiotic prophylaxis for urinary tract infections after removal of urinary catheter: meta-analysis. BMJ. 2013, 346:f3147. 10.1136/bmj.f3147

48. van Hees BC, Vijverberg PL, Hoorntje LE, Wiltink EH, Go PM, Tersmette M: Single-dose antibiotic prophylaxis for urinary catheter removal does not reduce the risk of urinary tract infection in surgical patients: a randomized double-blind placebo-controlled trial. Clin Microbiol Infect. 2011, 17:1091-4. 10.1111/j.1469-0691.2010.03447.X

49. Berrondo C, Feng C, Kukreja JB, et al.: Antibiotic prophylaxis at the time of catheter removal after radical prostatectomy: a prospective randomized clinical trial. Urol Oncol. 2019, 37:181-7. 10.1016/j.urolonc.2018.10.029

50. Foxman B, Cronenwett AE, Spino C, Berger MB, Morgan DM: Cranberry juice capsules and urinary tract infection after surgery: results of a randomized trial. Am J Obstet Gynecol. 2015, 213:194.e1-8. 10.1016/j.ajog.2015.04.003 
51. Gunnarsson AK, Gunningberg L, Larsson S, Jonsson KB: Cranberry juice concentrate does not significantly decrease the incidence of acquired bacteriuria in female hip fracture patients receiving urine catheter: a double-blind randomized trial. Clin Interv Aging. 2017, 12:137-43. 10.2147/CIA.S113597

52. Niël-Weise BS, van den Broek PJ: Antibiotic prophylaxis for short-term catheter bladder drainage in adults . Cochrane Database Syst Rev. 2005, 3:CD005428. 10.1002\%2F14651858.CD005428.pub2

53. Cardenas DD, Moore KN, Dannels-McClure A, Scelza WM, Graves DE, Brooks M, Busch AK: Intermittent catheterization with a hydrophilic-coated catheter delays urinary tract infections in acute spinal cord injury: a prospective, randomized, multicenter trial. PM R. 2011, 3:408-17. 10.1016/j.pmrj.2011.01.001

54. Fasugba O, Koerner J, Mitchell BG, Gardner A: Meatal cleaning with antiseptics for the prevention of catheter-associated urinary tract infections: A discussion paper. Infect Dis Health. 2017, 22:136-43. 10.1016/.i.idh.2017.06.004

55. Loeb M, Hunt D, O'Halloran K, Carusone SC, Dafoe N, Walter SD: Stop orders to reduce inappropriate urinary catheterization in hospitalized patients: a randomized controlled trial. J Gen Intern Med. 2008, 23:816-20. 10.1007/s11606-008-0620-2

56. Meddings I, Rogers MA, Macy M, Saint S: Systematic review and meta-analysis: reminder systems to reduce catheter-associated urinary tract infections and urinary catheter use in hospitalized patients. Clin Infect Dis. 2010, 51:550-60. 10.1086/655133

57. Chen YY, Chi MM, Chen YC, Chan YJ, Chou SS, Wang FD: Using a criteria-based reminder to reduce use of indwelling urinary catheters and decrease urinary tract infections. Am J Crit Care. 2013, 22:105-14. 10.4037/ajcc2013464

58. Lee KC, Chao YF, Wang YM, Lin PC: A nurse-family partnership intervention to increase the self-efficacy of family caregivers and reduce catheter-associated urinary tract infection in catheterized patients. Int J Nurs Pract. 2015, 21:771-9. 10.1111/iin.12319

59. Mody L, Krein SL, Saint S, et al.: A targeted infection prevention intervention in nursing home residents with indwelling devices: a randomized clinical trial. JAMA Intern Med. 2015, 175:714-23. 10.1001/jamainternmed.2015.132

60. Wilde MH, McMahon JM, McDonald MV, et al.: Self-management intervention for long-term indwelling urinary catheter users: randomized clinical trial. Nurs Res. 2015, 64:24-34. 10.1097/NNR.000000000000007

61. Durant DJ: Nurse-driven protocols and the prevention of catheter-associated urinary tract infections: A systematic review. Am J Infect Control. 2017, 45:1331-41. 10.1016/j.ajic.2017.07.020

62. Gould D, Gaze S, Drey N, Cooper T: Implementing clinical guidelines to prevent catheter-associated urinary tract infections and improve catheter care in nursing homes: Systematic review. Am J Infect Control. 2017, 45:471-6. 10.1016/j.ajic.2016.09.015

63. Meddings J, Saint S, Krein SL, et al.: Systematic review of interventions to reduce urinary tract infection in nursing home residents. J Hosp Med. 2017, 12:356-68. 10.12788/jhm.2724

64. Potugari BR, Umukoro PE, Vedre JG: Multimodal intervention approach reduces catheter-associated urinary tract infections in a rural tertiary care center. Clin Med Res. 2020, 18:140-144. 10.3121/cmr.2020.1533

65. Phipps S, Lim YN, McClinton S, Barry C, Rane A, N'Dow J: Short term urinary catheter policies following urogenital surgery in adults. Cochrane Database Syst Rev. 2006, 2:CD004374. 10.1002/14651858.CD004374.pub2

66. Kringel U, Reimer T, Tomczak S, Green S, Kundt G, Gerber B: Postoperative infections due to bladder catheters after anterior colporrhaphy: a prospective, randomized three-arm study. Int Urogynecol J. 2010, 21:1499-504. 10.1007/s00192-010-1221-2

67. Abdel-Aleem H, Aboelnasr MF, Jayousi TM, et al.: Indwelling bladder catheterisation as part of intraoperative and postoperative care for caesarean section. Cochrane Database Syst Rev. 2014 10.1002/14651858.CD010322.pub2

68. Goneau LW, Yeoh NS, MacDonald KW, Cadieux PA, Burton JP, Razvi H, Reid G: Selective target inactivation rather than global metabolic dormancy causes antibiotic tolerance in uropathogens. Antimicrob Agents Chemother. 2014, 58:2089-97. 10.1128/AAC.02552-13

69. Tambyah PA, Oon J: Catheter-associated urinary tract infection. Curr Opin Infect Dis. 2012, 25:365-70. 10.1097/QCO.0b013e32835565cc

70. Warren JW, Tenney JH, Hoopes JM, Muncie HL, Anthony WC: A prospective microbiologic study of bacteriuria in patients with chronic indwelling urethral catheters. J Infect Dis. 1982, 146:719-23. 10.1093/infdis/146.6.719

71. Zimlichman E, Henderson D, Tamir O, et al.: Health care-associated infections: a meta-analysis of costs and financial impact on the US health care system. JAMA Intern Med. 2013, 173:2039-46. 10.1001/jamainternmed.2013.9763

72. Lo E, Nicolle LE, Coffin SE, et al.: Strategies to prevent catheter-associated urinary tract infections in acute care hospitals: 2014 update. Infect Control Hosp Epidemiol. 2014, 35:464-79. 10.1086/675718

73. Nicolle LE: Urinary catheter-associated infections. Infect Dis Clin North Am. 2012, 26:13-27. 10.1016/i.idc. 2011.09.009

74. Titsworth WL, Hester J, Correia T, et al.: Reduction of catheter-associated urinary tract infections among patients in a neurological intensive care unit: a single institution's success. J Neurosurg. 2012, 116:911-20. 10.3171/2011.11.JNS11974

75. Lobdell KW, Stamou S, Sanchez JA: Hospital-acquired infections. Surg Clin North Am. 2012, 92:65-77. 10.1016/j.suc. 2011.11 .003

76. Gray M: Reducing catheter-associated urinary tract infection in the critical care unit . AACN Adv Crit Care. 2010, 21:247-257. 10.1097/nci.0b013e3181db53cb

77. R. Douglas Scott II: The Direct Medical Costs of Healthcare-Associated Infections in U.S. Hospitals and the Benefits of Prevention. Daniel A. Pollock, Patricia W. Stone (ed): Centers for Disease Control and Prevention, 2009.

78. Saint S, Wiese J, Amory JK, et al.: Are physicians aware of which of their patients have an indwelling urinary catheters?. Am J Med. 2000:476-480. 10.1016/s0002-9343(00)00531-3

79. Hutton DW, Krein SL, Saint S, et al.: Economic evaluation of a catheter-associated urinary tract infection prevention program in nursing homes. J Am Geriatr Soc. 2018, 66:742-747. 10.1111/igs.15316

80. Duszynska W, Rosenthal VD, Szczesny A, Zajaczkowska K, Fulek M, Tomaszewski J: Device associated health care associated infections monitoring, prevention and cost assessment at intensive care unit of University Hospital in Poland (2015-2017). BMC Infect Dis. 2020, 20:761. 10.1186/s12879-020-05482-W

81. Greene MT, Chang R, Kuhn L, Rogers MA, Chenoweth CE, Shuman E, Saint S: Predictors of hospitalacquired urinary tract-related bloodstream infection. Infect Control Hosp Epidemiol. 2012, 33:1001-7. $10.1086 / 667731$

82. Russo PL, Cheng AC, Richards M, Graves N, Hall L: Variation in health care-associated infection surveillance practices in Australia. Am J Infect Control. 2015, 43:773-5. 10.1016/j.ajic.2015.02.029

83. Mitchell BG, Hall L, Halton K, et al.: Time spent by infection control professionals undertaking healthcare associated infection surveillance: a multi-centred cross sectional study. Infect, Disease \& Health. 2016, 21:36-40. 10.1016/j.idh.2016.03.003

84. Saint S, Kowalski CP, Kaufman SR, et al.: Preventing hospital-acquired urinary tract infection in the United 


\section{Cureus}

States: a national study. Clin Infect Dis. 2008, 46:243-50. 10.1086/524662 